Rhode Island College

Digital Commons @ RIC

$5-13-2020$

\title{
Propofol Versus Midazolam on Reducing the Incidence of Post- Operative Nausea and Vomiting: A Systematic Review
}

Kimberly Luckett

Follow this and additional works at: https://digitalcommons.ric.edu/etd

Part of the Nursing Commons

\section{Recommended Citation}

Luckett, Kimberly, "Propofol Versus Midazolam on Reducing the Incidence of Post-Operative Nausea and Vomiting: A Systematic Review" (2020). Master's Theses, Dissertations, Graduate Research and Major Papers Overview. 356.

https://digitalcommons.ric.edu/etd/356

This Major Paper is brought to you for free and open access by the Master's Theses, Dissertations, Graduate Research and Major Papers at Digital Commons @ RIC. It has been accepted for inclusion in Master's Theses, Dissertations, Graduate Research and Major Papers Overview by an authorized administrator of Digital Commons @ RIC. For more information, please contact digitalcommons@ric.edu. 
PROPOFOL VERSUS MIDAZOLAM ON REDUCING THE INCIDENCE OF POSTOPERATIVE NAUSEA AND VOMITING: A SYSTEMATIC REVIEW

Kimberly Luckett

A Major Paper Submitted in Partial Fulfillment of the Requirements for the Degree of

Master of Science in Nursing

in

The School of Nursing

Rhode Island College 


\begin{abstract}
Post-operative nausea and vomiting (PONV) is defined as the occurrence of nausea, vomiting or retching after a surgical procedure either in post anesthesia care unit or within 24 hours after surgery. Post-operative nausea and vomiting, the second leading problem faced in the post anesthesia care unit, can affect $30-80 \%$ of surgical patients based on patient-specific and anesthetic specific risk factors. There are several medications used routinely to prevent and/ or reduce the incidence of PONV. The purpose of this systematic review was to investigate the efficacy of propofol compared to midazolam on reducing the incidence of PONV in the adult population after general anesthesia. A database search was conducted using inclusion and exclusion criteria to select pertinent research articles from 2009 to 2019. The PRISMA framework was utilized to guide the review and assist with article selection. Then, the CASP checklist guided the appraisal of each article included in the review. Data collection tables were created, and a cross-study analysis was conducted to explore the results of each article. Studies showed that both propofol and midazolam have anti-emetic properties even though the mechanisms of action are not truly understood. Overall, propofol and midazolam alone or in combination with other anti-emetics showed significant reduction in PONV and rescue anti-emetic requirement. By incorporating the use of propofol or midazolam into the anesthetic plan, anesthesia providers will be able reduce the incidence of PONV and decrease the associated adverse outcomes.
\end{abstract}




\section{Table of Contents}

Background/Statement of the Problem ................................................................. 1

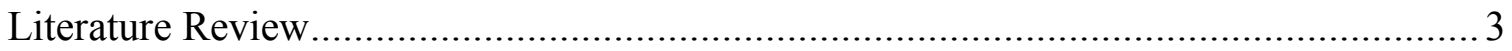

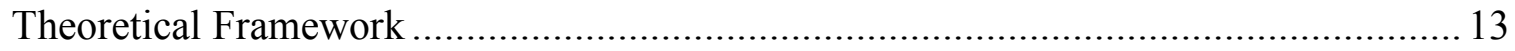

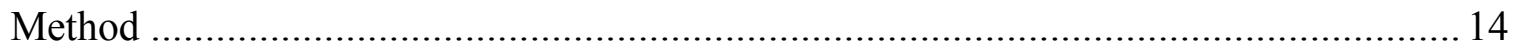

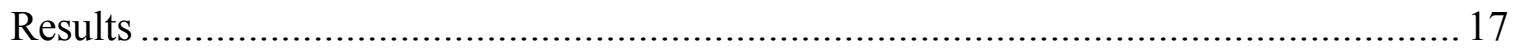

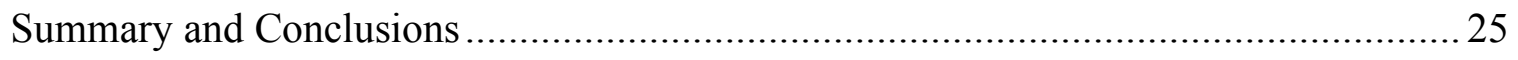

Recommendations and Implications for Advanced Nursing Practice ......................... 27

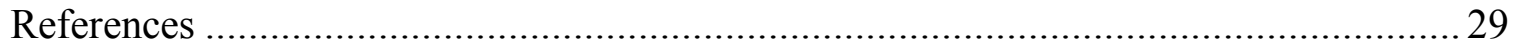

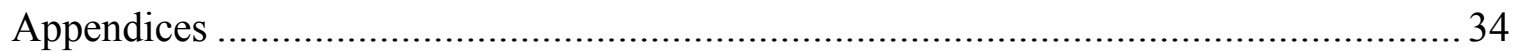


Propofol Versus Midazolam on Reducing the Incidence of Post-Operative Nausea and Vomiting: A Systematic Review

\section{Background/Statement of the Problem}

Post-operative nausea and vomiting (PONV) is defined as the occurrence of nausea, vomiting or retching after a surgical procedure either in the post-anesthesia care unit (PACU) or within 24 hours after surgery (Horn, Wallisch, Homantics \& Williams, 2013). PONV, the second leading problem faced in the PACU, can affect $30-80 \%$ of surgical patients based on patient-specific and anesthetic specific risk factors (Nagelhout \& Elisha, 2018). The risk factors that increase the incidence of PONV include female gender, non-smoker, history of PONV, history of motion sickness, and age less than 50 years old. Anesthetic related factors include use of volatile gases, use of nitrous oxide, duration of the surgery, and post-operative opioid use. According to Shaikh, Nagarekha, Hegade \& Marutheesh (2016), the type and length of surgery contributes to the risk as well. The Society for Ambulatory Anesthesia (SAMBA), a multidisciplinary panel of professionals, have implemented evidence-based guidelines and recommendations for use of antiemetic prophylaxis and treatment for post-operative nausea and vomiting (Nagelhout \& Elisha, 2018). The guidelines identify risk factors, suggest strategies for reducing PONV, identify effective therapies for prophylactically treating PONV (monotherapy and multimodal), and recommend treatment for active PONV (Gan et al., 2007). SAMBA further implemented an algorithm for the management PONV for atrisk individuals (Gan et al., 2007).

Post-operative nausea and vomiting (PONV) contributes to unfavorable consequences like delayed recovery, aspiration, hospital admission or increased length of stay, wound dehiscence and dehydration (Shaikh et al., 2016). For many decades, PONV has been a problem for surgical patients due to its complex mechanism (Gibbison \& 
Spencer, 2009). Extensive research has been conducted involving the effects of general anesthesia on the incidence of post-operative nausea and vomiting. Prevention and treatment of PONV involves a multimodal approach (Nagelhout, 2018).

Propofol, a short acting intravenous anesthetic, decreases the level of consciousness and results in lack of memory of medical events. This medication has proven to decrease the incidence of PONV in surgical patients receiving general anesthesia. General anesthesia can be delivered via total intravenous anesthesia, using volatile inhalation agents or a combination of both (Nagelhout \& Elisha, 2018). The largest challenge with general anesthesia is determining the best anesthetic plan for each patient to reduce or prevent post-operative nausea and vomiting.

Midazolam, a benzodiazepine, is commonly used in anesthesia as a sedative, anxiolytic, amnestic, and hypnotic drug (Nagelhout, 2018). According to Samimi Sade, Davari Tanha \& Sadeghi (2010), the anti-emetic properties of midazolam are not completely understood but presumed to act at the chemoreceptor trigger zone (CRTZ).

The purpose of this systematic review was to investigate the efficacy of propofol compared to midazolam on reducing the incidence of post-operative nausea and vomiting in the adult population after general anesthesia.

Next, the literature review will be discussed. 


\section{Literature Review}

A review of literature was performed to investigate the efficacy of propofol compared to midazolam at reducing the incidence of post-operative nausea and vomiting in the adult population after general anesthesia. Research articles were obtained by conducting a through database search on CINAHL, Medline, PubMed, and Google Scholar. The search terms included general anesthesia, general anesthesia side effects, post-operative nausea and vomiting, propofol, midazolam, PONV prevention, prophylaxis treatment of post-operative nausea and vomiting, and anti-emetics. Random control trials, meta-analyses, and prospective cohort studies from 2009 to 2019 were included in the literature review.

\section{Post-operative Nausea and Vomiting}

Post-operative nausea and vomiting is defined as the occurrence of nausea, vomiting or retching after a surgical procedure either in PACU or within 24 hours after surgery (Horn, Wallisch, Homantics \& Williams, 2014). PONV, the second leading problem faced in the post-anesthesia care unit, can affect $30-80 \%$ of surgical patients based on patient-specific and anesthetic specific risk factors (Abdelhamid \& Kamel,2014). According to Horn et al. (2014), patients reported that PONV is the most distressing adverse effect of anesthesia. The "vomiting center" (VC) in the medulla oblongata is comprised of the reticular formation, a network of nuclei clusters and the chemoreceptor trigger zone (CTZ) (Hall, 2011). The VC connects to the nucleus tractus solitarius (NTS) that receives input from cardiovascular, respiratory, genital, and digestive organs (Becker, 2010). The VC is activated by receiving many signals from sensory nerves in the gastrointestinal tract (peripheral pathways), the CTZ, cerebral cortex, and vestibular system (Moon, 2014). Stimulation to the forebrain pathway causes nausea and stimulation of the hindbrain pathway results in coordinated parasympathetic 
and efferent nerve responses to produce vomiting (Moon, 2014). The CTZ consists of receptors for dopamine, serotonin, acetylcholine, opioids, and substance $\mathrm{P}$ The zone is located outside of the blood brain barrier, therefore, this area of the brain is susceptible to stimulation from medications, toxins, and metabolites triggering vomiting (Becker, 2010).

The American Society of Anesthesiologists (ASA) created a classification system to access a patient's physical status prior to surgery (Abouleish, Leib, \& Cohen, 2015). There are six categories ranging from a healthy individual without systemic disease to an individual that is declared brain-dead and/ or an organ donation candidate. Class I represents a healthy individual with no past medical history and class II involves some type of past medical history, prescribed medication or controlled systemic disease process.

The study by Joe, Lee, Kim, Chang, Jeong, Jeong, \& Park (2016) consisted of 72 adult women with an ASA I or II that were randomly divided into the sevoflurane (volatile anesthetic gas) group or total intravenous anesthesia group using propofol. A nausea severity scale was used for evaluation purposes. The collected data included the incidence of post-operative nausea and vomiting, nausea, and vomiting in early (0-6 hours), late (6-24 hours), and overall (0-24 hours) and pain scores.

The study showed the use of both intravenous propofol and a rescue antiemetic, ramosetron, a serotonin type 3 receptor antagonist $\left(5-\mathrm{HT}_{3}\right)$, had significant reduction on the incidence of PONV compared to the sevoflurane (volatile anesthetic gas) group. The incidence of PONV in the early post-operative period in the total intravenous anesthesia group was 4 (11.1\%) compared to the Sevoflurane group which was 20 (55.6\%) with a $\mathrm{P}<0.001$ (Joe et al., 2016). In the late period (6-24 hours), PONV in the intravenous propofol group was $6(16.7 \%)$ compared to $11(30.6 \%)$ and the overall 
incidence of PONV was 7 (19.4\%) compared to $22(61.1 \%)$ with $\mathrm{P}=0.001(\mathrm{P}<0.05$ considered statistically significant) (Joe et al., 2016). The study suggested TIVA with propofol effectively reduces the incidence of PONV compared to using volatile gases such as sevoflurane.

\section{Risk Factors for Post-operative Nausea and Vomiting}

The patient-related risk factors of PONV include female gender, non-smoker, history of PONV, history of motion sickness, and age less than 50 years old. Anesthetic related factors include use of volatile gases, use of nitrous oxide, duration and type of the surgery, and post-operative opioid use (Moon,2014). Risk of PONV may be quantified by using the Apfel scoring system consisting of four factors. The Apfel score ranges from 0-4, predicting the percentage of PONV risk in the first 24 hours post-operatively.

Öbrink, Jidenstål, Oddby \& Jakobsson (2015) suggested that providing opioid free anesthesia is effective at reducing the incidence of post-operative nausea (68\% vs. $27 \%$ ) and vomiting ( $32 \%$ vs $8 \%$ ). Horn et al. (2014) suggested that increased duration of surgery, tissue trauma, and inflammation contribute to the incidence of PONV.

According to Pierre \& Whelan (2013), dose dependent opioid use intraoperatively and post-operatively increased the risk of PONV. "Opioids reduce muscle tone and peristaltic activity, thereby delaying gastric emptying, inducing distention, and triggering the vomiting reflex" (Pierre \& Whelan, 2013, pg. 29). The most common procedures that increase the incidence of PONV include abdominal, orthopedic, gynecologic, and middle ear surgeries (Arcangelo \& Peterson, 2013). PONV contributes to unfavorable consequences like delayed recovery, aspiration, hospital admission or increased length of stay, wound dehiscence and dehydration (Shaikh et al., 2016).

In 2015, the study by Naghibi, Kashefi, Azarnoush \& Zabihi consisted of 104 adult subjects with an ASA status of I or II that underwent lower abdominal surgery 
electively. The subjects were randomly divided into one of the four groups, the control, 20mg propofol, 30mg propofol, or the $10 \mathrm{mg}$ metoclopramide group (Naghibi et al., 2015). Naghibi et al. (2015) revealed in the first six hours following surgery both propofol groups showed decreased incidence of PONV with $23.08 \%$ and $15.38 \%$ in group 1 and 2 respectively developing PONV. The study further suggested that the propofol $30 \mathrm{mg}$ group and the metoclopramide $10 \mathrm{mg}$ group were comparable at decreasing the incidence of PONV compared to the control group developing PONV (Naghibi et al., 2015).

Obtaining a complete pre-anesthesia assessment is crucial to prevent and reduce the incidence of post-operative nausea and vomiting (Arcangelo \& Peterson, 2013). Reviewing the patient's chart and interviewing the patient on day of surgery can potentially alert the advanced practice provider to any risk factors for developing PONV.

\section{Pharmacological Therapies}

The main objective is prevention and reduction of the incidence of PONV to improve patient satisfaction and potentially reduce health care costs related to untoward effects of anesthesia. Anti-emetic preventative medications consist of serotonin antagonists, antihistamines-anticholinergics, corticosteroids, phenothiazines, butyrophenones, benzodiazepines, propofol, and the more recent neurokinin 1 antagonists (Shaikh et al., 2016). The most common anti-emetics used in the operative setting consist of serotonin antagonists $\left(5 \mathrm{HT}_{3}\right)$, corticosteroids, dopamine receptor antagonists, antihistamine-anticholinergics, and more recently propofol and benzodiazepines (Moon, 2014). According to Shaikh et al. (2016), PONV is a multifactorial adverse effect of general anesthesia and effective treatment involves a multimodal approach. 


\section{Serotonin antagonists.}

Serotonin receptor antagonists $\left(5 \mathrm{HT}_{3}\right)$ are used as preventative and rescue treatment for PONV in the post-operative acute care unit (PACU) (Horn et al., 2014). This class of medication involves antagonism of both peripheral and central afferent receptors that cause nausea and vomiting (Horn et al., 2014). Ondansetron (Zofran) is the anti-emetic commonly used in the peri-operative setting. Typical dosing of Zofran consists of $4 \mathrm{mg}$ intravenous dose given either after induction of anesthesia or towards the end of the surgery. The adverse effects include headache, abdominal pain, malaise, increased liver enzymes, and potential prolongation of the QT interval (Arcangelo \& Peterson, 2013).

\section{Corticosteroids.}

Corticosteroids or steroid hormones are produced in the adrenal cortex and are involved in several processes throughout the body such as stress response, inflammation, immune response, metabolism of carbohydrates and synthesis of proteins (Nagelhout \& Elisha, 2018). Steroid hormones are classified as glucocorticoids or mineralocorticoids. Glucocorticoids are anti-inflammatory, immunosuppressive, vasoconstrictive, and proliferative and mineralocorticoids regulate electrolyte and fluid balance (Nagelhout \& Elisha, 2018). Dexamethasone, the commonly used synthetic corticosteroid is almost like pure glucocorticoids found in the adrenal cortex (Ho, Wu, Ho, \& Wang, 2011). In the intra-operative setting, dexamethasone is used in conjunction with ondansetron to prevent PONV after general anesthesia however, the mechanism of action for dexamethasone remains unclear (Ho et al., 2011). Even though corticosteroids have adverse effects with long term use, a single anti-emetic dose is relatively safe though contraindicated in diabetics unless benefit outweighs the risk (Nagelhout \& Elisha, 2018).

The randomized control study by Heidari, Talakoub \& Yaraghi (2012), consisted 
of 66 subjects undergoing elective middle ear surgery. The study compared the effects of midazolam and midazolam-dexamethasone on the prevention of PONV. The subjects were divided into two groups: midazolam (M) group that received $0.075 \mathrm{mg} / \mathrm{kg}$ and the midazolam/ dexamethasone $(\mathrm{M}+\mathrm{D})$ group that received $0.075 \mathrm{mg} / \mathrm{kg}$ of midazolam plus $0.05 \mathrm{mg} / \mathrm{kg}$ of dexamethasone after induction. Nausea severity was measured in PACU at time intervals of 6,12 , and 24 hours after surgery using the visual analog scale $(0-10)$. The rescue anti-emetic used was metoclopramide $0.1 \mathrm{mg} / \mathrm{kg}$ if the VAS score was above 3 or vomiting was present. This data was collected along with the length of stay in PACU. The study revealed less vomiting frequency in the combination group in PACU $(0 \pm 0), 6-12 \mathrm{~h}(0.3 \pm 0.8)$, and $12-24 \mathrm{~h}(0.03 \pm 0.17)$ and reduced rescue anti-emetic requirements in the first 24 hours post-surgery in the combination group $(\mathrm{P}<0.05)$. The study suggested the use of both midazolam and dexamethasone to effectively prevent PONV compared to midazolam alone.

\section{Antihistamines-anticholinergics.}

Antihistamines-anticholinergics are two classes of medication that include agents used for mild nausea and motion sickness however, scopolamine has been used cautiously in the operative setting due to post-operative delirium in the older population. "Scopolamine is a competitive inhibitor at postganglionic muscarinic receptors in the parasympathetic nervous system and acts directly on the central nervous system by antagonizing cholinergic transmission in the vestibular nuclei” (Horn et al., 2014, pg. 8). The mechanism of action involves the visceral sensory pathways that contribute to nausea and vomiting (Arcangelo \& Peterson, 2013). The scopolamine patch is used for surgical patients with a history of severe motion sickness (Horn et al., 2014).

\section{Dopamine antagonists.}

According to Moon (2014), dopamine receptors, mainly $\mathrm{D}_{2}$ and $\mathrm{D}_{3}$, are shown to 
induce nausea and vomiting by reducing cAMP in the vomiting center of the brain (Moon, 2014). Of the dopamine antagonists, metoclopramide (Reglan) and droperidol are the common medications used as part of a multimodal approach in preventing and treating post-operative nausea and vomiting (Nagelhout \& Elisha, 2018). Droperidol is a selective dopamine $\mathrm{D}_{2}$ receptor antagonist. Horn et al. (2014) suggested that droperidol is as effective as dexamethasone or ondansetron at preventing PONV. The most common side effects include restlessness, minimal effect on sedation, QT prolongation, and ventricular arrhythmias (Horn et al., 2014). According to Gan (2004), cases of QT prolongation and/or torsade de pointes have been reported, therefore the FDA suggested droperidol be used with caution and reserved for use when other anti-emetics fail (Gan, 2004 ). FDA further suggested the use of droperidol was contraindicated for patients with known or suspected QT prolongation, including patients with congenital long QT syndrome (FDA, 2020) . Metoclopramide, a potent $\mathrm{D}_{2}$ receptor antagonist, also blocks $\mathrm{H}_{1}$

and $5-\mathrm{HT}_{3}$ receptors that enhances gastrointestinal motility, leading to an anti-emetic effect (Moon, 2014).

Honarmand, Safavi, Khalili, \& Mohammadnejad (2012) conducted a randomized, double-blind, placebo-controlled study consisting of 80 adult subjects scheduled for middle ear surgery under general anesthesia. The subjects were randomly allocated into one of four groups: control (C), midazolam (M), haloperidol (H), or haloperidol plus midazolam (HM) group. Subjects were evaluated by collecting data on incidence of PONV, post-operative pain, extra- pyramidal side effects, arrhythmias, and headache at 0-2 hours and 2-24 hours post anesthesia (Honarmand et al., 2012). The authors revealed the incidence of PONV in the $\mathrm{H}$ group was 12 (60\%), M group 13 (65\%), HM group 5 (25\%) and C group 20 (100\%) (Honarmand et al., 2012). The HM group also had the 
highest incidence of complete response with $70 \%$ of the group denying PONV (Honarmand et al., 2012). The study suggested that midazolam in combination with haloperidol decreases the incidence of PONV in the first 24 hours post anesthesia (Honarnamd et al., 2012).

\section{Propofol.}

Propofol, a lipophilic, sedative hypnotic medication, is commonly utilized for induction and maintenance of anesthesia. Due to the quick onset and short duration of action, propofol can be utilized for procedural sedation in the intensive care unit or the endoscopy department (Nagelhout \& Elisha, 2018). The anti-emetic mechanism of action for propofol still remains unclear however several mechanisms have been proposed. The proposals suggest that propofol directly depresses the vagal nuclei, the chemoreceptor trigger zone, and other areas contributing to nausea and vomiting (Miller \& Gan, 2015).

The study by Kim, Park, Kang, Choi, and Lee (2014), was a prospective, doubleblind, randomized control trial of 107 women scheduled for a laparoscopy-assisted vaginal hysterectomy. The authors evaluated the anti-emetic efficacy of propofol when administered at the conclusion of surgery (Kim et al., 2014). The women were divided into three randomized groups: the control group, the $0.5 \mathrm{mg} / \mathrm{kg}$ propofol group, and the $1 \mathrm{mg} / \mathrm{kg}$ propofol group. Data was collected on pain level, nausea, time spent in the postoperative unit, and use of rescue anti-emetics (Kim et al., 2014). The authors revealed that the incidence of nausea was significantly lower in the two propofol groups compared to the control group $(12.1 \%, 14.7 \%$, and $40 \%$ respectively). The results showed that a low dose of propofol can reduce the occurrence of PONV in the post anesthesia care unit (Kim et al., 2014).

Another study consisted of 120 subjects divided into three groups: propofol 
group, dexamethasone group, and control group (Celik et al., 2015). The data collected consisted of the incidence of nausea, vomiting, and rescue anti-emetic requirement. Data was recorded at the following intervals: 0-6 hours, 6-12 hours, and 12-24 hours post anesthesia using a four-point post-operative nausea and vomiting scale (Celik et al., 2015). The authors stated that the anti-emetic effects of propofol and dexamethasone were equivalent for the prevention of PONV in the first 24 hours post anesthesia. The study by Yimer, Ayalew, Abdisa \& Aregawi (2017), was a prospective cohort study of 72 adults scheduled for open abdominal surgery. The authors evaluated the efficacy of sub hypnotic dose of propofol on the incidence and severity of PONV. The subjects were evenly allocated into two groups: the propofol and non-propofol group. Data collection included the incidence of PONV at intervals of $0-6 \mathrm{~h}, 6-12 \mathrm{~h}, 12-24 \mathrm{~h}$, hemodynamic parameters, respiratory depression, severity of nausea and any side effects. (Yimer et al., 2017). The severity of nausea was assessed utilizing a 11-point numerical scoring system and the Bellville scoring tool to assess nausea and vomiting. The authors revealed that propofol at sub-hypnotic doses reduce the incidence of PONV in patients undergoing abdominal surgery electively and emergently. According to Yimer et al., (2017), the need for rescue anti-emetics was decreased in the propofol group compared to the non-propofol group.

\section{Midazolam.}

Midazolam, a benzodiazepine, is commonly used pre-operatively because of the anxiolytic and amnestic properties of the medication. The proposed anti-emetic mechanism of action of midazolam involves the reduction of dopamine input at the CTZ and potentially decreasing adenosine reuptake (Nagelhout \& Elisha, 2018). According to the meta-analysis by Grant et al. (2016) the use of midazolam significantly reduced rescue antiemetic requirement for the prevention of post-operative nausea and vomiting 
in the adult population. The authors further suggested that the use of midazolam alone or in combination with other antiemetics showed significant reduction in the incidence of PONV, nausea, and vomiting within the first 24 hours post anesthesia (Grant et al., 2016).

Another study consisting of 54 subjects scheduled for intragastric balloon insertion was divided into two groups: ondansetron and ondansetron/ midazolam group (Abdelhamid \& Kamel, 2014). Subjects were evaluated by collecting data on the incidence of nausea and vomiting, degree of sedation, nausea and vomiting score and incidence of adverse effects in the first 24 hours post anesthesia (Abdelhamid \& Kamel, 2014). The authors revealed the incidence of nausea and vomiting was 17 (66\% of subjects) in the ondansetron group and 9 (34.5\% of subjects) in the ondansetron/ midazolam group. The authors further suggested the use of midazolam as an adjunct provides a significant reduction in PONV (Abdelhamid \& Kamel, 2014).

Next, the theoretical framework will be discussed. 


\section{Theoretical Framework}

In 2009, the Preferred Reporting Items of Systematic reviews and Meta-Analyses (PRISMA) statement or framework was developed to guide systematic review research. This framework was used to guide this major project. The PRISMA framework consists of a four-phase flow diagram and a 27- item checklist (Liberati, Altman, Tetzlaff, Mulrow, Gøtzsche et al., 2009). The flow diagram (See Appendix A) helps identify and organize research articles obtained for analysis based on inclusion and exclusion criteria (Liberati et al., 2009). The four phases are identification, screening, eligibility, and included. The checklist (See Appendix B) helps to analyze, organize, and develop a comprehensive selection of research articles for the systematic review (Liberati et al., 2009). The checklist consists of six main sections: title, abstract, introduction, methods, results, discussion, and funding. There are 27 subsections included in this organizational checklist.

Post-operative nausea and vomiting has been extensively researched by anesthesiologists, certified registered nurse anesthetists, and a combination of both over the past ten years (Gibbison \& Spencer, 2009). The pharmaceuticals used to manage PONV have changed over the years from individual medications to a multimodal approach that is used currently. Conducting a thorough and valid systematic review is the goal of this major project. PRISMA provides a framework to accomplish this goal.

Next, the methods will be discussed. 


\section{Method}

\section{Purpose}

The purpose of this systematic review is to investigate the efficacy of propofol compared to midazolam on reducing the incidence of PONV in the adult population after general anesthesia.

\section{Inclusion/ Exclusion Criteria}

The inclusion criteria consisted of randomized control trials, meta-analyses, and cohort studies conducted within the last 10 years; adult subjects having elective surgery with general anesthesia; ASA I - II status; studies containing data for incidence of PONV, and articles in English. The PRISMA flowchart was utilized to identify and organize the articles based on this criterion.

The exclusion criteria consisted of articles published over 10 years ago, subjects under the age of 18 years old, subjects with history of drug or alcohol abuse, history of renal, kidney or liver disease and studies without data on the incidence of PONV after general anesthesia. The PRISMA flowchart was utilized to identify and organize the articles based on this criterion.

\section{Search Strategy}

Research articles were obtained by conducting a through database search on CINAHL, Medline, PubMed, and Google Scholar. The search terms included postoperative nausea and vomiting, general anesthesia side effects, propofol, midazolam, PONV prevention, prophylaxis treatment of PONV, and anti-emetics.

\section{Data Collection}

After article selection, two data collection tables were created for each article included in the systematic review. Table 1 includes the demographics of each study including citation, aim, design, sample, site, method, procedures, and results (See 
Appendix C).

Table 1

Demographics of Study

Citation

Aim Design Sample Method Procedures Medication Used/ Results

Table 2 contains the results of each study including the citation, incidence of nausea and vomiting, use of other anti-emetics, opioid use, induction/ maintenance medications, and limitations (See Appendix D).

Table 2

Study Results

Citation

N/V Rescue anti-emetics Induction/Maintenance Meds Side Effects Limitations

\section{Data Analysis}

The Critical Appraisal Skills Programme (CASP) was utilized to evaluate the validity of the research articles selected for this systematic review (Critical Appraisal Skills Programme, 2018). The CASP checklist (See Appendix E) consists of 10-questions to confirm that the selected studies correlate to the purpose of the systematic review. The checklist includes the following three sections: validity, results, and applicability to practice (Critical Appraisal Skills Programme, 2018). Once data collection and the CASP checklist was completed (See Appendix F), a cross-study analysis tables was created to analyze incidence of nausea and vomiting, use of other rescue anti-emetics, adverse effects, and opioid use (Table 3, See Appendix G). 
Table 3

Cross-Study Analysis

Study \# N/ V Rescue Anti-Emetics Adverse Effects Opioid Use

Next, the results will be discussed. 


\section{Results}

After a comprehensive database search 72 articles were retrieved for screening. The PRISMA flowchart (Appendix A) was used to guide, organize, eliminate duplicates, and further screen the appropriate articles based on inclusion and exclusion criteria. After duplicates were removed, 31 articles remained, 15 full text articles were then screened, and 7 more were then excluded based on lack of appropriate data. The eight remaining articles were included in the systematic review consisting of seven randomized control trials and one prospective cohort study. The results presented here were extracted from the data collection tables (Appendix D 1-8), and cross-study analysis table (Appendix G) created by the author.

The study by Abdelhamid et al. (2014) was a prospective randomized control trial consisting of 54 subjects aged 18-40 with an ASA physical status of I or II presenting for intragastric balloon insertion surgery. The incidence of PONV, nausea/ vomiting score, and degree of sedation were collected immediately in PACU, then at intervals of 30- and 60-minutes post-anesthesia. Incidence of adverse effects were collected during the first 24 hours post-anesthesia. The subjects were randomly allocated into two groups: ondansetron group (8mg) and the ondansetron / midazolam group (8mg/ 0.075mcg/kg). Anesthesia induction was universal in all cases using fentanyl, propofol, cisatracurium and maintenance consisted of propofol infusion. The data was analyzed using SPSS 18 software, Kolmogorov-Smirnov test, t-test, Chi-square test, Monte Carlo test, Fisher's exact test and $\mathrm{p}$ value of $<0.05$ was considered significant. The authors revealed the incidence of PONV in first 24 hours in ondansetron only group was 14 (56\%) compared to $10(34.5 \%)$ in the ondansetron/ midazolam group $(\mathrm{P}=0.113)$. According to Abdelhamid et al. (2014) there was not significant reduction in incidence of PONV $(\mathrm{P}=0.113)$, however there was a significant difference in nausea/ vomiting scores 
$(\mathrm{P}=0.015)$ in the first 24-hour period. The study revealed in the ondansetron group (G1) $11(44 \%)$ without nausea or vomiting, 0 with nausea only, 4 (16\%) with vomiting only, and $10(40 \%)$ with both nausea and vomiting. They further revealed in the ondansetron/ midazolam group (G2) $19(65.5 \%)$ without nausea or vomiting, $3(10.3 \%)$ with nausea only, 0 with vomiting only, and 7 (24.1\%) with both nausea and vomiting. Regarding sedation, $20(80 \%)$ of ondansetron group were mildly sedated immediately post compared to $17(58.6 \%)$ in group $2(\mathrm{P}=0.018)$. Then 30 minutes after surgery zero were mildly sedated in ondansetron group compared to $7(24.1 \%)$ in group $2(\mathrm{P}=0.012)$. The limitations of this study included lack of control group, no other side effect data was collected other than sedation, uneven subjects per group, and no mention of rescue antiemetic requirement. The authors suggested that midazolam/ ondansetron significantly reduced the severity of PONV according to nausea/ vomiting scores but not the overall incidence of PONV.

The randomized, double blind, placebo-controlled study by Celik et al. (2014) consisted of 120 adult subjects, both male and female with ASA status I or II presenting for laparoscopic cholecystectomy. The purpose of the study was to evaluate the efficacy of sub-hypnotic dose propofol with dexamethasone on the incidence of PONV. The subjects were randomly assigned to one of three groups: propofol, dexamethasone, or the control group $(\mathrm{n}=40)$. The data collected included incidence of PONV, rescue antiemetic requirement, and rescue analgesic needed in the first 24 hours post-surgery. Nausea, vomiting and anti-emetic usage was recorded at intervals of $0-6 \mathrm{~h}, 6-12 \mathrm{~h}$, and $12-$ 24h. The visual analog scale and PONV four-point scale were used to quantify nausea and severity of vomiting. Induction of anesthesia was universal for all cases using thiopental sodium $5 \mathrm{mg} / \mathrm{kg}$, fentanyl $1 \mathrm{mcg} / \mathrm{kg}$, and rocuronium for paralytic. Anesthesia was maintained with $1-2.5 \%$ sevoflurane, $50 \%$ oxygen and fentanyl $1 \mathrm{mcg} / \mathrm{kg} / \mathrm{h}$ in the 
dexamethasone group(Group D) and propofol infusion $1 \mathrm{mg} / \mathrm{kg} / \mathrm{h}$ in propofol group (Group P). The data was analyzed using the program of SPSS 20, ANOVA, Chi-test and a $p$ value of $<0.05$ was considered significant. The study revealed significant reduction in PONV between the control group and the group P and group D at all three-time intervals $(\mathrm{P}<0.05)$. At the $0-6 \mathrm{~h}$ interval $65 \%$ of the control group experienced PONV compared to $30 \%$ in the other two groups $(\mathrm{P}<0.05)$. At the $6-12 \mathrm{~h}$ interval there was a significant reduction among the groups, $52.5 \%$ of control group, $25 \%$ of propofol group, $20 \%$ of dexamethasone group experienced PONV ( $\mathrm{P}<0.05$ when compared to control group). The study also showed significant difference in number of subjects requiring rescue antiemetics in the control group 13 (32.5\%) compared to the propofol group $4(10 \%)$ and the dexamethasone group $4(10 \%)(\mathrm{P}=0.01$ for both). There was no significant difference in analgesic requirements between the propofol and dexamethasone groups, however there was a significant difference between the control and dexamethasone groups $(\mathrm{P}=0.04)$.

The next randomized control study by Heidari et al. (2012) consisted of 66 subjects aged 18-65 with an ASA status of I or II presenting for elective middle ear surgery. The subjects weighed less than $100 \mathrm{~kg}$ without history of motion sickness or PONV and denied hypersensitivity to midazolam or dexamethasone. The aim of this study was to compare the efficacy of midazolam and midazolam plus dexamethasone on the incidence of PONV. The subjects were randomly divided into two groups: the midazolam group $(0.075 \mathrm{mg} / \mathrm{kg})$ and the midazolam $(0.075 \mathrm{mg} / \mathrm{kg})$ plus dexamethasone $(0.05 \mathrm{mg} / \mathrm{kg})$ group. Induction and maintenance of anesthesia were standardized for all subjects. Data collection consisted of the incidence of PONV, severity of nausea/ vomiting measured via VAS (0-10) in PACU, 0-6h, 6-12h, and 12-24h intervals and rescue anti-emetic requirements. The data was analyzed with a Chi-square, t-test, and $p$ value $<0.05$ was considered significant. The authors revealed a mean nausea score of 
$1.39 \pm 3.19$ in the midazolam group $(\mathrm{P}=0.049)$ and $0.42 \pm 1.71$ in the midazolam/ dexamethasone group $(\mathrm{P}=0.049)$ and rescue anti-emetic requirements were higher in the midazolam group $(12.9 \pm 23.44 \mathrm{mg})$ compared to the combination group $(6.48 \pm 9.54 \mathrm{mg})$ ( $\mathrm{P}<0.05$ for both). The mean vomiting frequency in the PACU $(\mathrm{P}=0.039)$, at intervals of 6-12h $(\mathrm{P}=0.04)$ and $12-24 \mathrm{~h}(\mathrm{P}=0.047)$ were significantly different between the groups. The authors revealed that midazolam does have some anti-emetic properties however in combination with dexamethasone the effects were superior to single medication therapy. The limitations of this study included lack of control group and small sample size therefore, further studies would be needed to better compare these medications on preventing and / or reducing the incidence of PONV.

The randomized, double-blind, placebo-controlled study by Honarmand et al. (2012) consisted of 80 subjects aged 18-60 with an ASA status of I or II presenting for middle ear surgery under general anesthesia. The subjects were randomly and evenly allocated into one of four groups $(n=20)$. The haloperidol group $(2 \mathrm{mg})$, midazolam group ( $2 \mathrm{mg})$, haloperidol/ midazolam group ( $2 \mathrm{mg}$ of each), or the control group (saline). Both induction and maintenance of anesthesia were standardized in all cases. The data collection consisted of incidence of PONV, complete response to treatment, pain, occurrence of side effects (arrhythmias, headache), and rescue anti-emetic requirement at three intervals: $0-2 \mathrm{~h}, 2-24 \mathrm{~h}, 0-24 \mathrm{~h}$. Tests used to analyze data were ANOVA, Pearson Chi-square test, Fisher's exact test, Mann-Whitney U-test, SPSS 16.0 software and p value of $<0.05$ was considered significant. The authors revealed comparable complete response between the haloperidol and control group with $20 \%$ of the group without PONV. The midazolam group had a $45 \%$ complete response $(\mathrm{P}<0.05)$ and the haloperidol/ midazolam had a $70 \%$ complete response $(\mathrm{P}<0.05)$. Further comparison revealed that haloperidol/midazolam was more effective than midazolam only at the 2- 
24h and $0-24 \mathrm{~h}$ intervals ( $\mathrm{P}<0.05$ for both). According to Honarmand et al. (2012), the midazolam and haloperidol group rescue anti-emetic requirements were comparable however the haloperidol/midazolam group requirement $(0.5 \pm 1.5 \mathrm{mg})$ was significantly less than the other three groups [2.0-6.5 $\pm 4.1-4.6 \mathrm{mg}(\mathrm{p}<0.05)]$. The study further revealed no significant differences in side effects, sedation, VAS score, or post-operative analgesic requirement. The limitations of the study included small sample size and severity of nausea was not evaluated.

Next, the prospective randomized study by Joe et al. (2016) consisted of 72 females aged 20-60 with an ASA status of I or II presenting for thyroidectomy under general anesthesia. The purpose of study was to evaluate the efficacy of combined ramosetron and total intravenous anesthesia (TIVA) on the incidence of PONV. The subjects were allocated into either the sevoflurane group or the TIVA with ramosetron group $(n=36)$. Data collection included incidence and severity of PONV and rescue antiemetic requirements for each group at intervals of 0-6h, 6-24h, and 0-24h post-surgery. The data was analyzed using SPSS 17.0 program, Student's t-test, $\mathrm{x}^{2}$-test, and $\mathrm{p}$ values of $<0.05$ were considered significant. The study revealed a significant reduction of PONV and reduced rescue anti-emetic requirements in the TIVA group at all intervals compared to the other group. In the first $24 \mathrm{~h}, 7(19.4 \%)$ in TIVA group and $22(61.1 \%)$ in sevoflurane group experienced PONV ( $\mathrm{P}=0.001)$, and $4(11.1 \%)$ and $15(41.7 \%)$ needed rescue anti-emetic respectively $(\mathrm{P}=0.007)$. Therefore, the authors suggest the use of TIVA over the use of volatile anesthetics at reducing the incidence of PONV. The limitations of this study include lack of TIVA control group and small sample size.

The prospective, double-blind randomized control study by Kim et al. (2014) consisted of 107 females with ASA status of I or II presenting for laparoscopy assisted vaginal hysterectomy under general anesthesia. The aim of this study was to evaluate the 
antiemetic effect of varying doses of propofol given prior to end of surgery. The subjects were allocated into 1 of 3 groups: the propofol $0.5 \mathrm{mg} / \mathrm{kg}$ group, propofol $1 \mathrm{mg} / \mathrm{kg}$ group or the control saline group. Induction and maintenance of anesthesia were universal for all cases and propofol or saline were given 15 minutes prior to end of case. Data collection included incidence of PONV and nausea/vomiting severity at $0-2 \mathrm{~h}, 2-24 \mathrm{~h}$, and 24-48h post-surgery. The data was analyzed using SPSS 18.0, Sigma Stat 12.0, Chisquare test, Fisher's exact test, ANOVA, and a p value of $<0.05$ was considered significant. The authors used the visual analog scale (0-10) to quantify nausea/ vomiting severity. The study revealed a significant reduction of PONV $(\mathrm{P}=0.007)$ and less need for rescue anti-emetics $(\mathrm{P}=0.026)$ in both the propofol groups compared to the control group. At the $0-2 \mathrm{~h}$ interval, the incidence of PONV for the control group was 16 $(\mathrm{P}=0.007)$, propofol $(0.5 \mathrm{mg} / \mathrm{kg}) 4(\mathrm{P}=00.07)$, and propofol $(1 \mathrm{mg} / \mathrm{kg}) 5(\mathrm{P}=0.007)$. The authors showed no significant difference between the propofol doses on the incidence of PONV (4 and 5 respectively) and rescue anti-emetic requirement ( 1 and 2 respectively). The authors further revealed prolonged emergence period in the propofol groups compared to the control group $(\mathrm{P}=0.038$ and $\mathrm{P}=0.006$ respectively). The limitations of this study includes relatively small sample size and no comparison between propofol and other anti-emetics. According to Kim et al. (2014) even though propofol prolonged emergence, it effectively reduced the incidence of PONV and rescue anti-emetic requirements, therefore proving to be a positive adjunct to the anesthetic plan.

Another prospective, randomized, double-blind, placebo-controlled study by Naghibi et al. (2015) consisted of 104 subjects aged 18-65 years with ASA status I or II and $\mathrm{BMI}<30 \mathrm{~kg} / \mathrm{m}^{2}$ presenting for elective lower abdominal surgery under general anesthesia. The purpose of this study was to compare the effects of sub-hypnotic dose of propofol with metoclopramide. The subjects were randomly assigned into 1 of 4 groups: 
propofol 20mg (G1), propofol 30mg (G2), metoclopramide 10mg (G3), or placebo saline group (G4). Data collection consisted of incidence and severity of PONV, side effects of anti-emetics, duration of surgery and recovery period recorded at $0-6 \mathrm{~h}, 6-12 \mathrm{~h}$, and $12-24 \mathrm{~h}$ intervals. Induction and maintenance of anesthesia was universal in all cases and baseline hemodynamic were also collected. The data was analyzed using SPSS 20 software, Student's t-test, $\mathrm{x}^{2}$ - test, ANOVA, and $\mathrm{p}$ value of $<0.05$ was considered significant. The study revealed significant reduction in PONV in the propofol groups compared to the control. The incidence of PONV 0-6h post-anesthesia was $6(23.08 \%)$ in G1 ( $\mathrm{P}=0.005), 4(15.38 \%)$ in $\mathrm{G} 2(\mathrm{P}=0.016), 4(15.38 \%)$ in $\mathrm{G} 3(\mathrm{P}=0.016)$, and $8(30.77 \%)$ in $\mathrm{G} 4(\mathrm{P}=0.005)$ (Kim et al., 2014). However, the propofol groups were comparable at reducing PONV and the propofol $30 \mathrm{mg}$ group was also comparable to the metoclopramide group $(\mathrm{P}=0.016)$. There was less rescue anti-emetic requirement in both propofol groups and metoclopramide group compared to the control group ( $\mathrm{P}=0.042)$. The authors revealed the mean dose of anti-emetic was comparable in both propofol group (5.2 $\pm 2.1 \mathrm{mg}$ vs $5 \pm 0.9 \mathrm{mg}$ ) and metoclopramide group $(6 \pm 1.8 \mathrm{mg})$. No side effects were noted in the study and limitations of this study included small sample size and subjects were followed for first 24 hours post-surgery.

Lastly a prospective cohort study by Yimer et al. (2017) consisted of 72 subjects aged 18 or older with ASA status of I or II presenting for open abdominal surgery under general anesthesia. The aim of this study was to assess the efficacy of sub-hypnotic dose of propofol on the incidence of PONV. Data collection included the incidence of PONV at intervals of $0-6 \mathrm{~h}, 6-12 \mathrm{~h}, 12-24 \mathrm{~h}$, hemodynamic parameters, respiratory depression, severity of nausea and any side effects. Induction and maintenance of anesthesia were universal for all cases. The data was analyzed using SPSS 20 software, Student's t-test, Fisher's exact test, Shapiro-Wilk normality test, Mann-Whitney U test, Chi-square test, 
and $\mathrm{p}$ value $<0.05$ was considered significant. The authors revealed significant reduction in PONV in the propofol group $11(30.6 \%)$ in the first 6 hours compared to the control group $24(66.7 \%)(\mathrm{P}=0.002)$, no significant differences in hemodynamic stability and respiratory depression and noted more severe nausea in the control group. The study also showed a significant reduction in rescue anti-emetic needed in the propofol group compared to the control group [5 (13.9\%) and $15(41.7 \%)$ respectively, $(\mathrm{P}=0.009)]$. The limitations of this study included lack of group randomization; lack of anti-emetic used after 6 hours post-surgery, and the subjects were followed for the first 24 hours postoperatively.

All eight research articles were analyzed using the CASP appraisal tool to evaluate the validity of the research article and applicability to practice (Appendix F 1-8). Seven of the eight articles had 9 out of 9 "yes" to the appraisal questions (Abdelhamid et al. F-1,Celik et al., F-2, Heidari et al. F-3, Honarmand et al. F-4, Joe et al. F-5,Kim et al. F-6, Naghibi et al. F-7). All seven articles were deemed valid for this systematic review and the results were applicable to advanced nursing practice. The article by Yimer et al. was a prospective cohort study and the subjects were not randomized but were evenly allocated to either the propofol group or non-propofol group. Even though the subjects were not randomized due to university rules, the nature and results of the study showed enough validity to be included in this systematic review. Furthermore, the results of this study were considered applicable to advanced nursing practice.

Next, summary and conclusions will be discussed. 


\section{Summary and Conclusions}

Post-operative nausea and vomiting (PONV) is defined as the occurrence of nausea, vomiting or retching after a surgical procedure either in PACU or within 24 hours after surgery (Horn, Wallisch, Homantics \& Williams, 2014). PONV, the second leading problem faced in the post-anesthesia care unit, can affect $30-80 \%$ of surgical patients based on patient-specific and anesthetic specific risk factors (Abdelhamid \& Kamel, 2014). The patient-related risk factors of PONV include female gender, non-smoker, history of PONV, history of motion sickness, and age less than 50 years old. Anesthetic related factors include use of volatile gases, use of nitrous oxide, duration, and type of the surgery, and post-operative opioid use (Moon,2014). PONV contributes to unfavorable consequences like delayed recovery, pulmonary aspiration, unexpected hospital admission or increased length of stay, delayed return to work, wound dehiscence and dehydration. Furthermore, risk of PONV may be quantified by using scoring systems such as the Apfel or the Visual Analog System (VAS). The Apfel scoring system consists of four factors: gender, smoking status, history of motion sickness or PONV, and use of post-operative opioids (Apfel et al. (2012). The Apfel score ranges from 0-4, predicting the percentage of PONV risk in the first 24 hours post-operatively. The VAS quantifies the severity of nausea / vomiting using a 0-10 scale.

A systematic review was conducted to investigate the efficacy of propofol compared to midazolam on reducing the incidence of post-operative nausea and vomiting in the adult population after general anesthesia. A review of literature was conducted using the PRISMA flow chart (Appendix A) along with inclusion and exclusion criteria set forth by the author. The data collected consisted of incidence of PONV, rescue antiemetic requirement, induction/ maintenance medication used, side effects, and limitations (Appendix D 1-8). Eight articles were included in the systematic review, 
seven random control trials and one prospective cohort study. Data collection tables were created, CASP checklist (See Appendix E \& F) was utilized to appraise each article included in the review and a cross-study analysis table (See Appendix G) was created and used to validate and compare the results of each article.

All the studies in this systematic review revealed that both propofol and midazolam possesses anti-emetic properties. The review further suggests that both medications significantly reduced the incidence of PONV (See Appendix D 1-8, Appendix G) and seven studies revealed reduction in rescue anti-emetic requirements with the use of either propofol or midazolam. However, four out of eight studies revealed a multimodal approach was far superior at reducing the incidence of PONV compared to single agent approach. The study by Heidari et al. (2012) showed midazolam alone was effective at reducing the incidence of PONV however adding dexamethasone had significant impact on reducing the incidence and reduced the antiemetic requirement by half. This systematic review supports the usage of these medications in a multimodal approach and proven effective at reducing and preventing PONV in the adult population after general anesthesia. Limitations to this study include limited number of studies analyzed for the review; type of surgeries involved in the studies because specific surgeries increase risk of PONV, one of the eight studies made no mention of rescue anti-emetics, and small sample sizes of some studies included in the systematic review.

In conclusion, both propofol and midazolam were shown to reduce the incidence and severity of PONV in the adult population following general anesthesia. The results of this systematic review can give certified registered nurse anesthetists (CRNA) more options in the multimodal approach in the preventing and reducing the incidence of PONV. Next, recommendations and implications for advanced nursing practice. 


\section{Recommendations and Implications for Advanced Nursing Practice}

The systematic review revealed information that can be valuable to the advanced practice provider to incorporate into practice in order to reduce and/ or prevent the incidence and/or severity of PONV in the adult population. PONV can affect $30-80 \%$ of the surgical population, therefore, CRNA's play a crucial role in planning and implementing treatment to reduce and/ or prevent incidence of PONV. Advanced practice providers incorporate evidence-based research, guidelines, and algorithms into daily practice, therefore, information obtained from this systematic review would be beneficial. Analyzing the risk factors can assist the CRNA at creating a more appropriate plan of care to decrease the incidence of PONV. Implementing protocols to prophylactically treat PONV would reduce the adverse outcomes of anesthesia.

As CRNAs, a through preoperative assessment is key to determining which patients are at increased risk of PONV by utilizing the assessment tools available (i.e., Apfel, Bellville). Discussing the potential risk with the patient can help to lessen anxiety and potentially reduce the risk of PONV. After determining the patient's risk of PONV, the anesthesia provider can utilize the SAMBA algorithm (see Figure 1) to create an appropriate plan of care (Hooper, 2015). As stated earlier, specific surgeries pose an increased risk for PONV and those patients would benefit from a multimodal approach for preventing and reducing PONV. CRNAs understand PONV is multifactorial and most patients require a minimum of two anti-emetics, therefore, adding a sub-hypnotic dose of propofol or pre-operative dose of midazolam proves safe and effective in prophylactically treating PONV. With guidelines or protocols in place and continuing education for anesthesia providers, prophylactically treating PONV shall become an easier task. Increased awareness of the multiple drug options for management shall help minimize the incidence of PONV, such as utilizing a preoperative sub-hypnotic 
midazolam dose not only for anxiolysis but also for the prevention of PONV. Even though this review suggests effective reduction of PONV with the use of propofol or midazolam alone or in combination with other anti-emetics, further research on this topic is needed due to rapid pharmaceutical advancements.

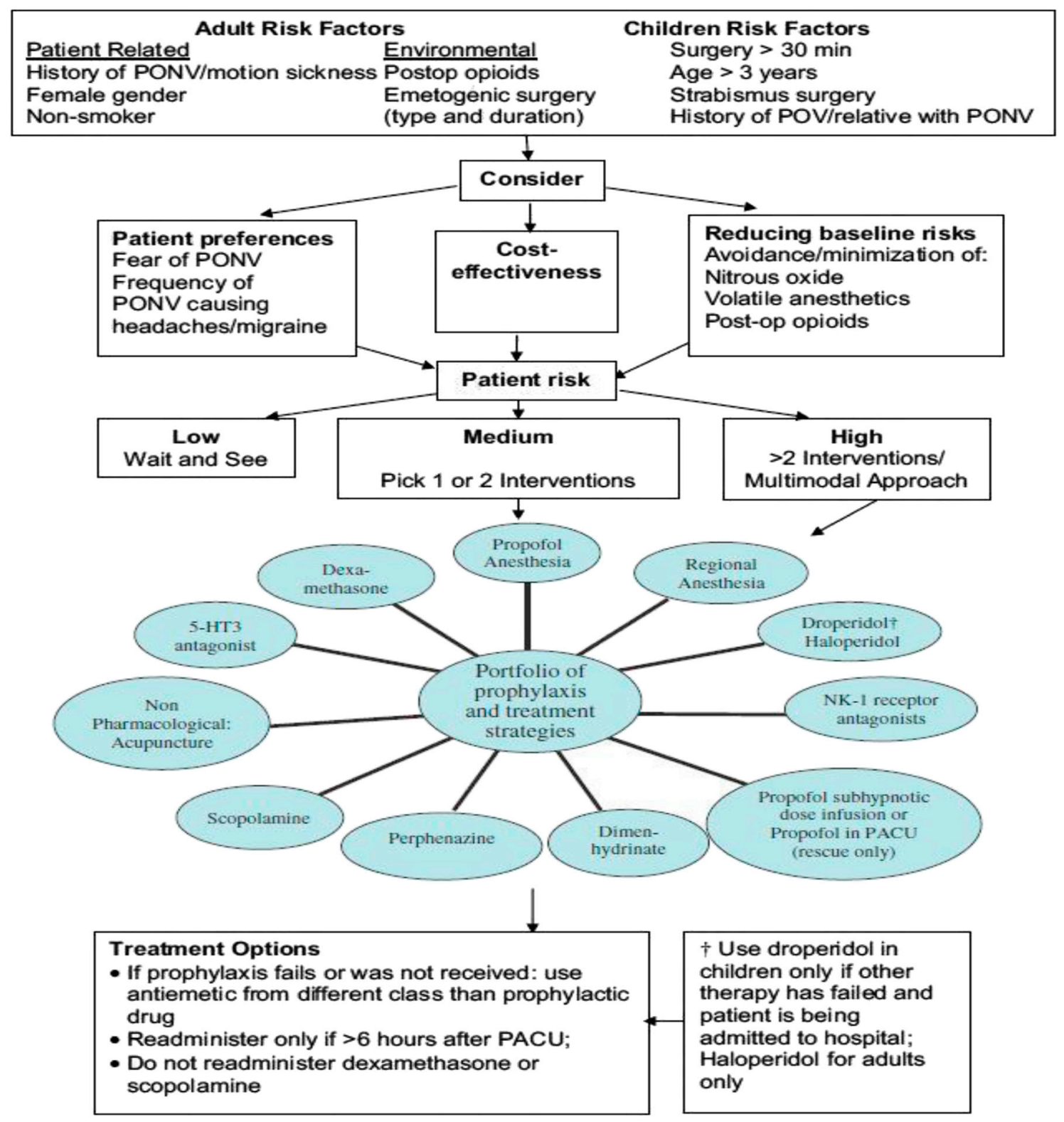

Hooper, V. (2015). SAMBA Consensus Guidelines for the Management of Postoperative Nausea and Vomiting: An Executive Summary for Perianesthesia Nurses. Journal of Perianesthesia Nursing, 30(5),377-382.

doi:https://doi.org/10.1016/j.jopan.2015.08.00

Figure 1 SAMBA Consensus Algorithm 


\section{References}

Abdelhamid, S. \& Kamel, M. (2014). A prospective controlled study to assess the antiemetic effect of midazolam following intragastric balloon insertion. Journal of Anesthesiology Clinical Pharmacology,30(3), 383-386. https://doi:10.4103/09709185.137272

Abouleish, A., Leib, M., \& Cohen, N. (2015). ASA provides examples to each ASA physical status class. ASA Monitor, 79: 38-39. http://monitor.pubs.asahq.org/article.aspx?articleid=2434536

Apfel, C., Heidrich, F., Jukar-Rao, S., Jalota, L., Hornuss, C., Whelan, R. Zhang, K., \& Cakmakkaya, O. (2012). Evidence-based analysis of risk factors for postoperative nausea and vomiting. British Journal of Anesthesia, 109 (5): 742-753. https://doi:10.1093/bja/aes276

Arcangelo, V. \& Peterson, A. (2013). Nausea and vomiting. In V. Arcangelo \& A. Peterson (Eds.), Pharmacotherapeutics for advanced practice. (pp. 392-409). Philadelphia, PA: Lippincott Williams \& Wilkins.

Becker, D. E. (2010). Nausea, vomiting, and hiccups: A review of mechanisms and treatment. The American Dental Society of Anesthesiology, 57:150-157.

Celik, M., Dostbil, A., Aksoy, M., Ince, I., Ahiskalioglu, A., Comez, M. \& Fuat Erdem, A. (2014). Is infusion of sub hypnotic propofol as effective as dexamethasone in prevention of post-operative nausea and vomiting related to laparoscopic cholecystectomy? A randomized controlled trial. BioMed Research International, 2015, 1-5. https://dx.doi.org/10.1155/2015/349806

Critical Appraisal Skills Programme (2018). CASP checklist. Retrieved from https://casp-uk.net/casp-tools-checklists11/aas.12921 
Gan, T. (2004). "Black Box” Warning on Droperidol: A Report of the FDA Convened Expert Panel, Anesthesia \& Analgesia: 98(6), 1809.

doi: 10.1213/01.ANE.0000121199.16379.A0

Gan, T., Meyer, T., Apfel, C., Chung, F., Davis, P., Habib, A., Hooper, V., Kovac, A., Kranke, P., Myles, P., Philip, B., Samsa, G., Sessler, D., Temo, J., Tramer, M., Kolk, C. \& Watcha, M. (2007). Society for ambulatory anesthesia guidelines for the management of postoperative nausea and vomiting. International Anesthesia Research Society, 105 (6), 1615-1628.

Gibbison, B. \& Spencer, R. (2009). Post-operative nausea and vomiting. Anesthesia \& Intensive Care Medicine. 10 (12): 583-585. doi:10.1016/j.mpaic.2009.09.006

Grant, M., Kim, J., Page, A., Hobson, D., Wick, E. \& Wu, C. (2016). The effect of intravenous midazolam on post-operative nausea and vomiting: A meta-analysis. International Anesthesia Research Society, 122(3), 656-663.

Hall, J. (2011). Digestion and Absorption in the Gastrointestinal Tract. In R. Gruliow \& L. Stingelin (Eds.), Guyton and Hall textbook of medical physiology (pp. 789798). Philadelphia, PA: Saunders Elsevier.

Heidari, S., Talakoub, R., \& Yaraghi, Z. (2012). Comparing the preventive effect of midazolam and midazolam-dexamethasone on postoperative nausea and vomiting in elective middle ear surgery. Advanced Biomedical Research, 1(9), 1-9. http://doi:10.4103/2277-9175.96052

Ho, C., Wu, H., Ho, S. \& Wang, J (2011). Dexamethasone prevents post-operative nausea and vomiting: Benefit versus risk. Acta Anaesthesiologica Taiwanica,49(2011), 100-104. http://doi:10.1016/j.aat.2011.06.002

Honarmand, A., Safavi, M., Khalili, G., \& Mohammadnejad, F. (2012). Prophylactic administration of haloperidol plus midazolam reduces postoperative nausea and 
vomiting better than using each drug alone in patients undergoing middle ear surgery. Saudi Journal of Anesthesia, 6(2),145-151. https://doi:10.4103/1658354X.97028Horn, C., Wallisch, W., Homanics, G. \& Williams, J. (2014). Pathophysiological and neurochemical mechanisms of post-operative nausea and vomiting. Eur J Pharmacol, 722, 55-66. http://doi:10.1016/j.ejphar.2013.10.037

Hooper, V. (2015). SAMBA Consensus Guidelines for the Management of Postoperative Nausea and Vomiting: An Executive Summary for Perianesthesia Nurses. Journal of Perianesthesia Nursing, 30(5),377-382. https://doi.org/10.1016/j.jopan.2015.08.00

Horn, C., Wallisch, W., Homanics, G. \& Williams, J. (2014). Pathophysiological and neurochemical mechanisms of post-operative nausea and vomiting. Eur $\mathbf{J}$ Pharmacol, 722, 55-66. http://doi:10.1016/j.ejphar.2013.10.037

Joe, H. B., Lee, S. Y., Kim, J.-S., Chang, H. S., Jeong, Y., Jeong, H., \& Park, S. Y. (2016). Effect of total intravenous anesthesia and prophylactic ramosetron on postoperative nausea and vomiting after thyroidectomy: A prospective, randomized controlled study. Journal of International Medical Research, 44(1), 81-88. https://doi.org/10.1177/0300060515607384

Kim, E., Park, H., Kang, H., Choi, J. \& Lee, H. (2014). Antiemetic effect of propofol administered at the end of surgery in laparoscopic assisted vaginal hysterectomy. The Korean Society of Anesthesiologists, 66(3): 210-215. http://dx.doi.org/10.4097/kjae.2014.66.3.210

Liberati, A., Altman, D.G., Tetzlaff, J., Mulrow, C., Gøtzsche, P.C., et al. (2009). The PRISMA Statement for Reporting Systematic Reviews and Meta-Analyses of Studies That Evaluate Health Care Interventions: Explanation and Elaboration. PLOS Medicine 6(7): e1000100. https://doi.org/10.1371/journal.pmed.1000100 Miller, T. \& Gan, T. (2015). Total intravenous anesthesia and anesthetic outcomes. 
Journal of Cardiothoracic and Vascular Anesthesia, 29(1), 11-15.

Moon, Y. E. (2014). Postoperative nausea and vomiting. Korean Journal of Anesthesiology, 67(3), 164-170. http://dx.doi.org/10.4097/kjae.2014.673.164

Nagelhout, J. J. \& Elisha, S. (2018). Post-anesthesia recovery. In J. Nagelhout \& S. Elisha (Eds.), Nurse anesthesia (pp. 1147-1166). St. Louis, MO: Elsevier.

Naghibi, K., Kashefi, P., Azamoush, H., \& Zabihi, P. (2015). Prevention of postoperative nausea and vomiting with sub hypnotic dose of propofol in patients undergoing lower abdominal surgery: A prospective, randomized, double-blind study. Advanced Biomedical Research, 4(35). https://doi:10.4103/2277-9175. 9151239

Öbrink, E., Jidenstål, P., Oddby, E. \& Jakobsson, J. (2015). Post-operative nausea and vomiting: Update on predicting the probability and ways to minimize its occurrence, with focus on ambulatory surgery. International Journal of Surgery,15(2015), 100-106. http://dx.doi.org/10.1016/j.ijsu.2015.01.024

Pierre, S. \& Whelan, R. (2013). Nausea and vomiting after surgery. British Journal of Anesthesia, 13 (2013), 28-32.

Samimi Sade, S., Davari Tanha, F., \& Sadeghi, S. (2010). Prevention of postoperative nausea and vomiting by administration of sub hypnotic doses of propofol and midazolam during spinal anesthesia for cesarean section. Journal of Family and Reproductive Health, 4(4), 175-178.

Shaikh, S., Nagerekha, D., Hegade, G. \& Marutheesh, M. (2016). Postoperative nausea and vomiting: A simple yet complex problem. Anesthesia Essays and Researches, 10(3), 388-396. Doi:10.4103/0259-1162.179310

U.S. Food and Drug Administration. (2020, May 6). U.S. Food and Drug Administration. https://www.fda.gov 
Yimer, H., Ayalew, N., Abdisa, Z. \& Aregawi, A. (2017). Effect of sub-hypnotic dose of propofol on prevention of postoperative nausea and vomiting as part of multimodal antiemetic in patients undergoing open abdominal surgery: A prospective cohort study. International Journal of Surgery Open, 10(2018), 1520. https://doi.org/10.1016/j.ijso.2017.11.008 


\section{Appendix A}

\section{PRISMA Flow Diagram}
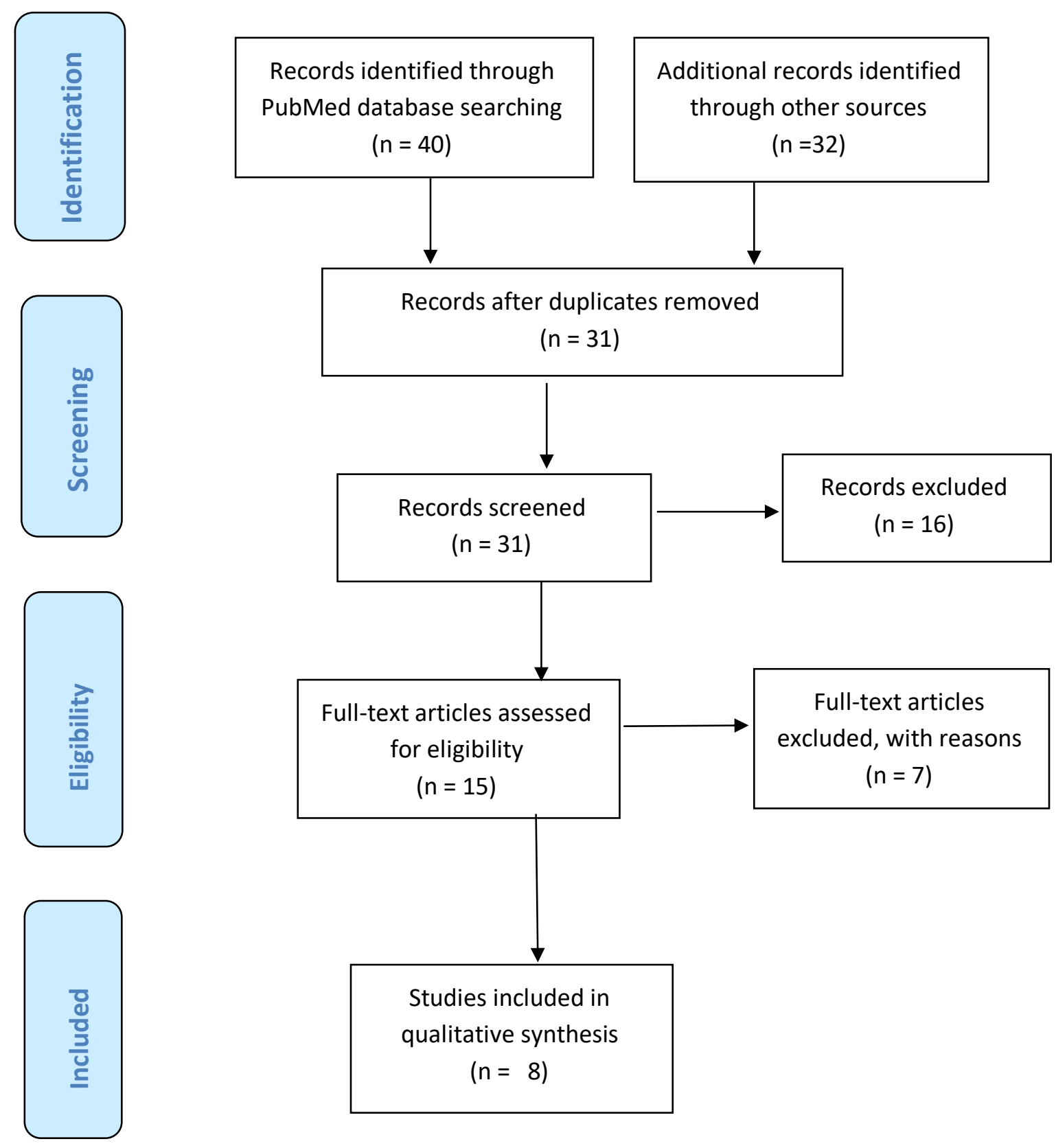

Moher D, Liberati A, Tetzlaff J, Altman DG, The PRISMA Group (2009). Preferred Reporting Items for Systematic Reviews and MetaAnalyses: The PRISMA Statement. PLoS Med 6(7): e1000097. doi:10.1371/journal.pmed1000097 


\section{Appendix B}

\section{PRISMA Checklist}

\begin{tabular}{|c|c|c|c|}
\hline Section/topic & $\#$ & Checklist item & $\begin{array}{l}\text { Reported } \\
\text { on page: }\end{array}$ \\
\hline \multicolumn{4}{|l|}{ TITLE } \\
\hline Title & 1 & Identify the report as a systematic review, meta-analysis, or both. & \\
\hline \multicolumn{4}{|l|}{ ABSTRACT } \\
\hline Structured summary & 2 & $\begin{array}{l}\text { Provide a structured summary including, as applicable: background; objectives; data sources; study eligibility criteria, } \\
\text { participants, and interventions; study appraisal and synthesis methods; results, limitations; conclusions and } \\
\text { implications of key findings; systematic review registration number. }\end{array}$ & \\
\hline \multicolumn{4}{|l|}{ INTRODUCTION } \\
\hline Rationale & 3 & Describe the rationale for the review in the context of what is already known. & \\
\hline Objectives & 4 & $\begin{array}{l}\text { Provide an explicit statement of questions being addressed with reference to participants, interventions, comparisons, } \\
\text { outcomes, and study design (PICOS). }\end{array}$ & \\
\hline \multicolumn{4}{|l|}{ METHODS } \\
\hline Protocol and registration & 5 & $\begin{array}{l}\text { Indicate if a review protocol exists, if and where it can be accessed (e.g., Web address), and, if available, provide } \\
\text { registration information including registration number. }\end{array}$ & \\
\hline Eligibility criteria & 6 & $\begin{array}{l}\text { Specify study characteristics (e.g., PICOS, length of follow-up) and report characteristics (e.g. years considered, } \\
\text { language, publication status) used as criteria for eligiblilty, giving rationale. }\end{array}$ & \\
\hline Information sources & 7 & $\begin{array}{l}\text { Describe all information sources (e.g., databases with dates of coverage, contact with study authors to identify } \\
\text { additional studies) in the search and date last searched. }\end{array}$ & \\
\hline Search & 8 & $\begin{array}{l}\text { Present full electronic search strategy for at least one database, including any limits used, such that it could be } \\
\text { repeated. }\end{array}$ & \\
\hline Study selection & 9 & $\begin{array}{l}\text { State the process for selecting studies (i.e., screening, eligibility, included in systematic review, and, if applicable, } \\
\text { included in the meta-analysis). }\end{array}$ & \\
\hline Data collection process & 10 & $\begin{array}{l}\text { Describe method of data extraction from reports (e.g., piloted forms, independently, in duplicate) and any processes } \\
\text { for obtaining and confirming data from investigators. }\end{array}$ & \\
\hline Data items & 11 & $\begin{array}{l}\text { List and define all variables for which data were sought (e.g., PICOS, funding sources) and any assumptions and } \\
\text { simplifications made. }\end{array}$ & \\
\hline $\begin{array}{l}\text { Risk of bias in individual } \\
\text { studies }\end{array}$ & 12 & $\begin{array}{l}\text { Describe methods used for assessing risk of bias of individual studies (including specification of whether this was } \\
\text { done at the study or outcome level), and how this information is to be used in any data synthesis. }\end{array}$ & \\
\hline Summary measures & 13 & State the principal summary measures (e.g., risk ratio, difference in means). & \\
\hline Synthesis of results & 14 & $\begin{array}{l}\text { Describe the methods of handling data and combining results of studies, if done, including measures of consistency } \\
\text { (e.g., l) for each meta-analysis. }\end{array}$ & \\
\hline
\end{tabular}

Page 1 of 2

Moher D, Liberati A, Tetzlaff J, Altman DG, The PRISMA Group (2009). Preferred Reporting Items for Systematic Reviews and Meta-Analyses: The PRISMA Statement. PLoS Med 6(6): e1000097. doi:10.1371/journal.pmed100009 


\section{PRISMA Checklist}

\begin{tabular}{|c|c|c|c|}
\hline Sectionltopic & \# & Checklistitem & $\begin{array}{l}\text { Reported } \\
\text { on page: }\end{array}$ \\
\hline Risk of bias across studies & 15 & $\begin{array}{l}\text { Specify any assessment of risk of bias that may affect the cumulative evidence (e.g., publication bias, selective } \\
\text { reporting within studies). }\end{array}$ & \\
\hline Additional analyses & 16 & $\begin{array}{l}\text { Describe methods of additional analyses (e.g., sensituity or subgroup analyses, meta-regression), if done, indicating } \\
\text { which were pre-specified. }\end{array}$ & \\
\hline \multicolumn{4}{|l|}{ RESULTS } \\
\hline Study selection & 17 & $\begin{array}{l}\text { Give numbers of studies screened, assessed for eligibility, and included in the review, with reasons for exclusions at } \\
\text { each stage, ideally with a flow diagram. }\end{array}$ & \\
\hline Study characteristics & 18 & $\begin{array}{l}\text { For each study, present characacteristics for which data were extracted (e.g., study size, PICOS, follow-up period) and } \\
\text { provide the citations. }\end{array}$ & \\
\hline Risk of bias within studies & 19 & Present data on risk of bias of each study and, if available, any outcome level assessment (see item 12). & \\
\hline Results of individual studies & 20 & $\begin{array}{l}\text { For all outcomes considered (benefits or harms), present, for each study: (a) simple summary data for each } \\
\text { intervention group (b) effect esimates and confidence intervals, ideally with a forest plot. }\end{array}$ & \\
\hline Synthesis of results & 21 & Present results of each meta-analysis done, including confidence intervals and measures of consistency. & \\
\hline Risk of bias across studies & 22 & Present results of any assessment of risk of bias across studies (see ltem 15). & \\
\hline Additional analysis & 23 & Give results of additional analyses, if done (e.g., sensitivity or subgroup analyses, meta-regression [see ltem 16]). & \\
\hline \multicolumn{4}{|l|}{ DISCUSSION } \\
\hline Summary of evidence & 24 & $\begin{array}{l}\text { Summarize the main findings including the strength of evidence for each main outcome', consider their relevance to } \\
\text { key groups (e.g., healthcare providers, users, and policy makers). }\end{array}$ & \\
\hline Limitations & 25 & $\begin{array}{l}\text { Discuss limitations at study and outcome level (e.g., risk of bias), and at review-level (e.g., incomplete retrieval of } \\
\text { identified research, reporting bias). }\end{array}$ & \\
\hline Conclusions & 26 & Provide a general interpretation of the results in the context of other evidence, and implications for future research. & \\
\hline \multicolumn{4}{|l|}{ FUNDING } \\
\hline Funding & 27 & $\begin{array}{l}\text { Describe sources of funding for the systematic review and other support (e.g., supply of data); ; role of funders for the } \\
\text { systematic review. }\end{array}$ & \\
\hline
\end{tabular}

Page 2 of 2

Moher D, Liberati A, Tetzlaff J, Altman DG, The PRISMA Group (2009). Preferred Reporting Items for Systematic Reviews and Meta-Analyses: The PRISMA Statement. PLoS Med 6(6): e1000097. doi:10.1371/journal.pmed1000097 


\section{Appendix C}

\section{Demographics of Study}

C-1: Abdelhamid, S. \& Kamel, M. (2014). A prospective controlled study to assess the antiemetic effect of midazolam following intragastric balloon insertion. Journal of Anesthesiology Clinical Pharmacology, 30(3), 383-386. https://doi:10.4103/0970-

9185.137272

\begin{tabular}{|c|c|c|c|c|c|}
\hline Aim/ Purpose & $\underline{\text { Design }}$ & Sample & Methods & $\underline{\text { Procedure }}$ & Medication Used/ Results \\
\hline $\begin{array}{l}\text { To investigate } \\
\text { the efficacy of } \\
\text { ondansetron and } \\
\text { midazolam at } \\
\text { reducing the } \\
\text { incidence of } \\
\text { PONV after } \\
\text { intragastric } \\
\text { balloon } \\
\text { insertion }\end{array}$ & $\begin{array}{l}\text { Prospective } \\
\text { controlled trial, } \\
\text { patients randomly } \\
\text { allocated into two } \\
\text { groups } \\
\text { Ondansetron group } \\
8 \mathrm{mg} \text { and } \\
\text { ondansetron/ } \\
\text { midazolam group } \\
8 \mathrm{mg} / 0.075 \mathrm{mcg} / \mathrm{kg} \\
\text { (based on total } \\
\text { body weight) }\end{array}$ & $\begin{array}{l}54 \text { subjects, aged } \\
18-40 \text {, ASA } \\
\text { physical status I - } \\
\text { II, BMI } 30-35 \\
\mathrm{~kg} / \mathrm{m}^{2} \text {, presenting } \\
\text { for intragastric } \\
\text { balloon insertion } \\
\text { surgery }\end{array}$ & $\begin{array}{l}\text { The incidence of } \\
\text { nausea and vomiting, } \\
\text { nausea/ vomiting } \\
\text { score, the degree of } \\
\text { sedation } \\
\text { (immediately, } 30 \\
\text { minutes, and } 60 \\
\text { minutes post- } \\
\text { anesthesia) incidence } \\
\text { of adverse effects } \\
\text { during the first } 24 \\
\text { hours post- } \\
\text { operatively } \\
\text { Anesthesia induction } \\
\text { and maintenance was } \\
\text { universal in all cases }\end{array}$ & $\begin{array}{l}\text { Elective } \\
\text { intragastric } \\
\text { balloon } \\
\text { insertion }\end{array}$ & $\begin{array}{l}\text { Ondansetron, } \\
\text { ondansetron/midazolam } \\
\text { Significant reduction in the } \\
\text { severity of PONV in the } \\
\text { combination group compared } \\
\text { to ondansetron group. } \\
\text { Mild sedation occurred in early } \\
\text { post-operative period. } \\
\text { Nausea/ vomiting during } 24 \mathrm{~h} \\
\text { post-operatively in group } 1 \\
\text { was } 56 \% \text { ( } 14 \text { subjects) and } \\
34.5 \% \text { ( } 10 \text { subjects) in group } 2\end{array}$ \\
\hline
\end{tabular}


C-2: Celik, M., Dostbil, A., Aksoy, M., Ince, I., Ahiskalioglu, A., Comez, M. \& Fuat Erdem, A. (2014). Is infusion of sub hypnotic propofol as effective as dexamethasone in prevention of post-operative nausea and vomiting related to laparoscopic cholecystectomy? A randomized controlled trial. BioMed Research International, 2015, 1-5. https://dx.doi.org/10.1155/2015/349806

\begin{tabular}{|c|c|c|c|c|c|}
\hline Aim/ Purpose & Design & $\underline{\text { Sample }}$ & Methods & Procedure & Medication Used/ Results \\
\hline $\begin{array}{l}\text { Evaluate the } \\
\text { efficacy of sub } \\
\text { hypnotic dose } \\
\text { of propofol } \\
\text { with } \\
\text { dexamethasone } \\
\text { on the } \\
\text { incidence of } \\
\text { PONV }\end{array}$ & $\begin{array}{l}\text { Randomized, } \\
\text { double blind, } \\
\text { placebo-controlled } \\
\text { trial } \\
\text { Subjects randomly } \\
\text { assigned to } 1 \text { of } 3 \\
\text { groups: propofol } \\
\text { (1mg/kg/h), } \\
\text { dexamethasone } \\
\text { (8mg), or control } \\
\text { group (10 \% } \\
\text { intralipid) }\end{array}$ & $\begin{array}{l}120 \text { Subjects, } \\
\text { both male/ } \\
\text { female, ASA } \\
\text { physical status I } \\
\text { or II presenting } \\
\text { for laparoscopic } \\
\text { cholecystectomy }\end{array}$ & $\begin{array}{l}\text { Incidence of PONV, need } \\
\text { for rescue anti-emetic or } \\
\text { rescue analgesic recorded } \\
\text { in the first } 24 \text { hours post } \\
\text { anesthesia } \\
\text { Nausea, vomiting, anti- } \\
\text { emetic use was recorded at } \\
3 \text { periods: 0-6hours, 6- } \\
12 \text { hours, and } 12-24 \text { hours } \\
\text { Visual Analog Scale and } \\
\text { PONV four-point scale } \\
\text { Anesthesia induction and } \\
\text { maintenance was universal } \\
\text { in all cases }\end{array}$ & $\begin{array}{l}\text { Laparoscopic } \\
\text { cholecystectomy }\end{array}$ & $\begin{array}{l}\text { Dexamethasone } 8 \mathrm{mg} \\
\text { Propofol } 1 \mathrm{mg} / \mathrm{kg} / \text { hour } \\
\text { Control } 10 \% \text { intralipids } \\
15 \text { minutes before skin } \\
\text { closure } \\
\text { Propofol and } \\
\text { dexamethasone were } \\
\text { comparable in 0-24-hour } \\
\text { post anesthesia period } \\
\text { Dexamethasone group } \\
\text { required less rescue anti- } \\
\text { emetic in 6-12 hours and } \\
12-24 \text { hours post } \\
\text { anesthesia }\end{array}$ \\
\hline
\end{tabular}


C-3: Heidari, S., Talakoub, R., \& Yaraghi, Z. (2012). Comparing the preventive effect of midazolam and midazolamdexamethasone on postoperative nausea and vomiting in elective middle ear surgery. Advanced Biomedical Research, 1(9), 1-9. http://doi:10.4103/2277-9175.96052

Aim/ Purpose
To evaluate the
efficacy of
midazolam and
midazolam plus
dexamethasone
on PONV after
middle ear
surgery

surgery

Design $\quad$ Sample

Randomized, 66 ASA I or II, aged double-blind, 18-65, weight $<$ controlled study $100 \mathrm{~kg}$ without history of motion sickness, pregnancy, hypersensitivity to either midazolam or dexamethasone, and PONV

\section{Methods}

Subjects randomly divided into 2 groups: midazolam (M)

$(0.075 \mathrm{mg} / \mathrm{kg})$ and midazolam $(0.075 \mathrm{mg} / \mathrm{kg})$ plus

dexamethasone $(\mathrm{M}+\mathrm{D})(0.05$ $\mathrm{mg} / \mathrm{kg}$ )

Induction/ maintenance standardized for all subjects, universal monitoring for all subjects

Severity of nausea /vomiting measured by visual analog scale in PACU, at 6,12, and 24h after surgery, rescue anti-emetics and PACU length of stay was also recorded

Rescue anti-emetic was metoclopramide $0.1 \mathrm{mg} / \mathrm{kg}$

\section{Procedure Medication Used/Results}

Elective No significant middle ear differences in age, surgery weight, and gender between the groups

Mean nausea score M group: $1.39 \pm 3.19$ $\mathrm{M}+\mathrm{D}$ group: $0.42 \pm 1.71$

Mean Vomiting frequency:

PACU: $0.9 \pm 0.29(\mathrm{M})$, $0 \pm 0(\mathrm{M}+\mathrm{D})$

6-12h: $1.09 \pm 2.41(\mathrm{M})$

$0.3 \pm 0.8(\mathrm{M}+\mathrm{D})$

12-24h: $0.42 \pm 1.32(\mathrm{M})$, $0.03 \pm 0.17$

Rescue Antiemetic M: $12.9 \pm 23.44$ $\mathrm{M}+\mathrm{D}: 6.48 \pm 9.54$ 
C-4: Honarmand, A., Safavi, M., Khalili, G., \& Mohammadnejad, F. (2012). Prophylactic administration of haloperidol plus midazolam reduces postoperative nausea and vomiting better than using each drug alone in patients undergoing middle ear surgery. Saudi Journal of Anesthesia, 6(2),145-151. https://doi:10.4103/1658-354X.97028

\begin{tabular}{|c|c|c|c|c|c|}
\hline Aim/Purpose & Design & $\underline{\text { Sample }}$ & Methods & Procedures & Medication used/ Results \\
\hline $\begin{array}{l}\text { To evaluate the } \\
\text { anti-emetic } \\
\text { effects of the } \\
\text { combination of } \\
\text { intravenous } \\
\text { midazolam with } \\
\text { haloperidol on } \\
\text { PONV in } \\
\text { comparison to } \\
\text { each medication } \\
\text { alone }\end{array}$ & $\begin{array}{l}\begin{array}{l}\text { Randomized, } \\
\text { double-blind, } \\
\text { placebo-controlled } \\
\text { study }(\mathrm{n}=80)\end{array} \\
4 \text { Groups: } \\
\text { Group H: }(\mathrm{n}=20) \\
\text { Haloperidol } 2 \mathrm{mg} \text { IV } \\
\text { Group M: }(\mathrm{n}=20) \\
\text { Midazolam } 2 \mathrm{mg} \mathrm{IV} \\
\text { Group HM: }(\mathrm{n}=20) \\
\text { Haloperidol } 2 \mathrm{mg} \text { IV } \\
\text { Midazolam } 2 \mathrm{mg} \text { IV } \\
\text { Group C: }(\mathrm{n}=20) \\
\text { Saline IV }\end{array}$ & $\begin{array}{l}80 \text { ASA status } \\
\text { I or II, aged } \\
\text { 18-60, under- } \\
\text { going surgery } \\
\text { with general } \\
\text { anesthesia }\end{array}$ & $\begin{array}{l}\text { Induction/ } \\
\text { maintenance of } \\
\text { anesthesia universal } \\
\text { Midazolam, } \\
\text { haloperidol or both } \\
\text { were given } 30 \text { min } \\
\text { before conclusion of } \\
\text { surgery } \\
\text { Data on incidence of } \\
\text { PONV, complete } \\
\text { response, pain, } \\
\text { occurrence of side } \\
\text { effects, arrhythmias, } \\
\text { rescue anti-emetics } \\
\text { and headache was } \\
\text { collected for } 0-2 \mathrm{~h}, 2- \\
24 \mathrm{~h}, \& 0-24 \mathrm{~h}, \mathrm{VAS} \\
\text { scoring system was } \\
\text { used }\end{array}$ & $\begin{array}{l}\text { Middle ear } \\
\text { surgery }\end{array}$ & $\begin{array}{l}\text { Group H: } \\
\text { Complete Response } 4(20 \%) \\
\text { 0-2h: } 6(30 \%) \\
\text { 2-24h: } 6(30 \%) \\
\text { 0-24h: } 12(60 \%) \\
\text { Group M: } \\
\text { Complete Response 9 }(45 \%) \\
\text { 0-2h: } 9(45 \%) \\
\text { 2-24h: } 4(20 \%) \\
\text { 0-24h: } 13(65 \%) \\
\text { Group HM: } \\
\text { Complete Response } 14 \\
\text { (70\%) } \\
\text { 0-2h: } 3(15 \%) \\
\text { 2-24h: } 2(10 \%) \\
\text { 0-24h: } 5(25 \%) \\
\text { Group C: } \\
\text { Complete Response } 4(20 \%) \\
\text { 0-2h: } 10(50 \%) \\
\text { 2-24h: } 10(50 \%) \\
\text { 0-24h: } 20(100 \%)\end{array}$ \\
\hline
\end{tabular}


C-5: Joe, H. B., Lee, S. Y., Kim, J.-S., Chang, H. S., Jeong, Y., Jeong, H., \& Park, S. Y. (2016). Effect of total intravenous anesthesia and prophylactic ramosetron on postoperative nausea and vomiting after thyroidectomy: A prospective, randomized controlled study. Journal of International Medical Research, 44(1), 81-88. https://doi.org/10.1177/0300060515607384

\begin{tabular}{|c|c|c|c|c|c|}
\hline Aim/ Purpose & $\underline{\text { Design }}$ & $\underline{\text { Sample }}$ & $\underline{\text { Methods }}$ & $\underline{\text { Procedures }}$ & $\underline{\text { Medication Used/ Results }}$ \\
\hline $\begin{array}{l}\text { To evaluate the } \\
\text { efficacy of } \\
\text { combined } \\
\text { ramosetron and } \\
\text { total intravenous } \\
\text { anesthesia } \\
\text { (TIVA) on post- } \\
\text { operative nausea } \\
\text { and vomiting }\end{array}$ & $\begin{array}{l}\text { A prospective } \\
\text { randomized } \\
\text { control study } \\
\text { Sevoflurane } \\
\text { group } \\
\text { TIVA plus } \\
\text { ramosetron } \\
\text { group }\end{array}$ & $\begin{array}{l}72 \text { women, } \\
\text { aged } 20-60 \text {, } \\
\text { ASA status } \\
\text { I or II }\end{array}$ & $\begin{array}{l}\text { Incidence and severity of } \\
\text { PONV, use of rescue anti- } \\
\text { emetics were recorded } \\
\text { during the first } 24 \mathrm{~h} \text { after } \\
\text { surgery } \\
\text { Sevoflurane group } \\
\text { induced with } 4-5 \mathrm{mg} / \mathrm{kg} \\
\text { thiopental sodium, } \\
\text { maintained with } \\
\text { sevoflurane in } 50 \% \\
\text { oxygen } \\
\text { TIVAR group } 0.3 \text { mg } \\
\text { ramsetron IV given prior } \\
\text { to induction with } \\
\text { remifentanil, propofol } \\
\text { All other medication was } \\
\text { universal in both groups } \\
\text { Post-operative } \\
\text { assessments made at } 1 \mathrm{~h} \text {, } \\
6 \mathrm{~h}, 24 \mathrm{~h}, \text { incidence of } \\
\text { PONV, rescue anti-emetic } \\
\text { used }\end{array}$ & $\begin{array}{l}\text { Thyroidectomy } \\
\text { under general } \\
\text { anesthesia }\end{array}$ & $\begin{array}{l}\text { TIVAR Group } \\
\text { 0-6h: } \\
\text { PONV: } 4 \text { (11.1\%) } \\
\text { Rescue Antiemetic: } 2(5.6 \%) \\
\text { 6-24h: } \\
\text { PONV: } 6(16.7 \%) \\
\text { Rescue Antiemetic: } 3(8.3 \%) \\
\text { 0-24h: } \\
\text { PONV: } 7(19.4 \%) \\
\text { Rescue Antiemetic: } 4 \text { (11.1\%) } \\
\text { Sevoflurane Group } \\
\text { 0-6h: } \\
\text { PONV: } 20(55.6 \%) \\
\text { Rescue Antiemetic: } 11 \\
\text { (32.4\%) } \\
\text { 6-24h: } \\
\text { PONV:11 (30.6\%) } \\
\text { Rescue Antiemetic: } 6(16.7 \%) \\
\text { 0-24h: } \\
\text { PONV: } 22 \text { (61.1\%) } \\
\text { Rescue Antiemetic: } 15 \\
\text { (41.7\%) }\end{array}$ \\
\hline
\end{tabular}


C-6: Kim, E., Park, H., Kang, H., Choi, J. \& Lee, H. (2014). Antiemetic effect of propofol administered at the end of surgery in laparoscopic assisted vaginal hysterectomy. The Korean Society of Anesthesiologists, 66(3): 210-215.

http://dx.doi.org/10.4097/kjae.2014.66.3.210

\begin{tabular}{|c|c|c|c|c|c|}
\hline Aim/ Purpose & Design & Sample & Methods & Procedure & $\underline{\text { Results }}$ \\
\hline $\begin{array}{l}\text { To evaluate the } \\
\text { efficacy of } \\
\text { varying doses of } \\
\text { propofol given } \\
15 \text { minutes prior } \\
\text { to the end of } \\
\text { surgery }\end{array}$ & $\begin{array}{l}\text { Prospective, } \\
\text { double-blind, } \\
\text { randomized } \\
\text { control study, } \\
\text { subjects randomly } \\
\text { placed into } 3 \\
\text { groups }(0.5 \mathrm{mg} / \mathrm{kg} \\
\text { propofol, } 1 \mathrm{mg} / \mathrm{kg} \\
\text { propofol, and } \\
\text { saline group }\end{array}$ & $\begin{array}{l}107 \text { women, } \\
\text { ASA physical } \\
\text { status I or II } \\
\text { presenting for } \\
\text { laparoscopy- } \\
\text { assisted } \\
\text { vaginal } \\
\text { hysterectomy } \\
\text { under general } \\
\text { anesthesia }\end{array}$ & $\begin{array}{l}\text { Visual Analog Scale (VAS) } \\
\text { Incidence of PONV post- } \\
\text { operative in time intervals } \\
(0-2 \text { hours, } 2-24 \text { hours, } 24-48 \\
\text { hours) } \\
\text { Anesthesia induction and } \\
\text { maintenance was universal in } \\
\text { all cases }\end{array}$ & $\begin{array}{l}\text { Laparoscopy- } \\
\text { assisted } \\
\text { vaginal } \\
\text { hysterectomy }\end{array}$ & $\begin{array}{l}0.5 \mathrm{mg} / \mathrm{kg} \text { propofol, } \\
1 \mathrm{mg} / \mathrm{kg} \text { propofol, } \\
\text { normal saline (control) } \\
\text { Incidence of nausea: } \\
0-2 \text { hours } \\
\text { Group 1: } 4(12 \%) \\
\text { Group 2: } 5(15 \%) \\
\text { Control: } 16(40 \%) \\
\text { Incidence of vomiting: } \\
\text { 0-2 hours } \\
\text { Group 1: } 0 \\
\text { Group 2: } 2 \text { (6\%) } \\
\text { Control: } 3 \text { (8\%) } \\
\text { No significant effect in } \\
\text { 2-24-hour, } 24-48 \text {-hour } \\
\text { intervals related to } \\
\text { PCA use }\end{array}$ \\
\hline
\end{tabular}


C-7: Naghibi, K., Kashefi, P., Azamoush, H., \& Zabihi, P. (2015). Prevention of postoperative nausea and vomiting with sub hypnotic dose of propofol in patients undergoing lower abdominal surgery: A prospective, randomized, double-blind study. Advanced Biomedical Research, 4(35). https://doi:10.4103/2277-9175.151239

\begin{tabular}{|c|c|}
\hline Aim/ Purpose & Design \\
\hline $\begin{array}{l}\text { Compare the } \\
\text { efficacy of } \\
\text { sub hypnotic } \\
\text { dose of }\end{array}$ & $\begin{array}{l}\text { Prospective, } \\
\text { randomized, double- } \\
\text { blind, placebo- } \\
\text { controlled study }\end{array}$ \\
\hline $\begin{array}{l}\text { metocloprami } \\
\text { de }\end{array}$ & $\begin{array}{l}\text { Randomly assigned } \\
\text { into } 1 \text { of } 4 \text { groups: } \\
\text { propofol } 20 \mathrm{mg} \text {, } \\
\text { propofol } 30 \mathrm{mg}, \\
\text { metoclopramide } 10 \\
\text { mg, placebo saline } \\
\text { group }\end{array}$ \\
\hline
\end{tabular}

Sample $\quad$ Methods

104 subjects, ASA physical status I or II, aged $18-65$ years, BMI $<30 \mathrm{~kg} / \mathrm{m}^{2}$ presenting for elective lower abdominal surgery under general anesthesia group

\section{Procedure Medication Used/Results \\ Elective lower Propofol $20 \mathrm{mg}$, abdominal Propofol $30 \mathrm{mg}$, surgery Metoclopramide $10 \mathrm{mg}$, or Saline given 15 minutes prior to skin closure \\ Propofol $30 \mathrm{mg}$ was slightly more effective than Metoclopramide 10 $\mathrm{mg}$ in the first 6 hours post anesthesia}

Baseline HR, SBP, DBP, MAP, \& $\mathrm{SaO}_{2}$ was collected

Anesthesia induction and maintenance was universal in all cases
Both groups had $15.39 \%$ $\mathrm{N} / \mathrm{V}$ but propofol group had lower mean dose of rescue anti-emetic 
C-8: Yimer, H., Ayalew, N., Abdisa, Z. \& Aregawi, A. (2017). Effect of sub-hypnotic dose of propofol on prevention of postoperative nausea and vomiting as part of multimodal antiemetic in patients undergoing open abdominal surgery: A prospective cohort study.

International Journal of Surgery Open, 10(2018), 15-20. https://doi.org/10.1016/j.ijso.2017.11.008

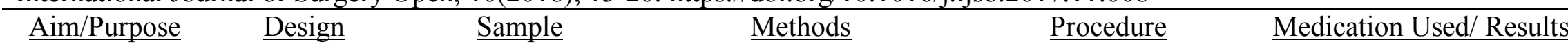

To assess the

efficacy of

sub-hypnotic

dose of

propofol on

incidence and

severity of

PONV after

having open

abdominal

surgery
Prospective 72 subjects, $>18$

observational

cohort study

Two groups:

Propofol

Control

$n=36 /$ group

or II, subjects

presenting for

open abdominal

surgery under years old, ASA I

general anesthesia

K

\section{Induction:}

Ketamine $2 \mathrm{mg} / \mathrm{kg}$ or

thiopental sodium

$5 \mathrm{mg} / \mathrm{kg}$, fentanyl

$0.1 \mathrm{mcg} / \mathrm{kg}$

Intubation:

Suxamethonium

Maintenance:

vecuronium halothane

with or without morphine

Reversal:

neostigmine $0.05 \mathrm{mg} / \mathrm{kg}$

Atropine $0.01 \mathrm{mg} / \mathrm{kg}$
Appendectomy,

resection and

anastomosis,

exploratory

laparotomy,

abdominal

hysterectomy,

cholecystectomy

Propofol

Reglan

Propofol group:

0-6h: $11(30.6 \%)$

6-12h: $8(22.2 \%)$

12-24h: 7 (19.4\%)

Control group:

0-6h: 24 (66.7\%)

6-12h: 14 (38.9\%)

12-24h: 9 (25\%)

No significant differences in hemodynamic stability, respiratory depression

Severity of nausea greater in control group 


\section{Appendix D}

\section{Results of Study}

D-1: Abdelhamid, S. \& Kamel, M. (2014). A prospective controlled study to assess the antiemetic effect of midazolam following intragastric balloon insertion. Journal of Anesthesiology Clinical Pharmacology, 30(3), 383-386. https://doi:10.4103/09709185.137272

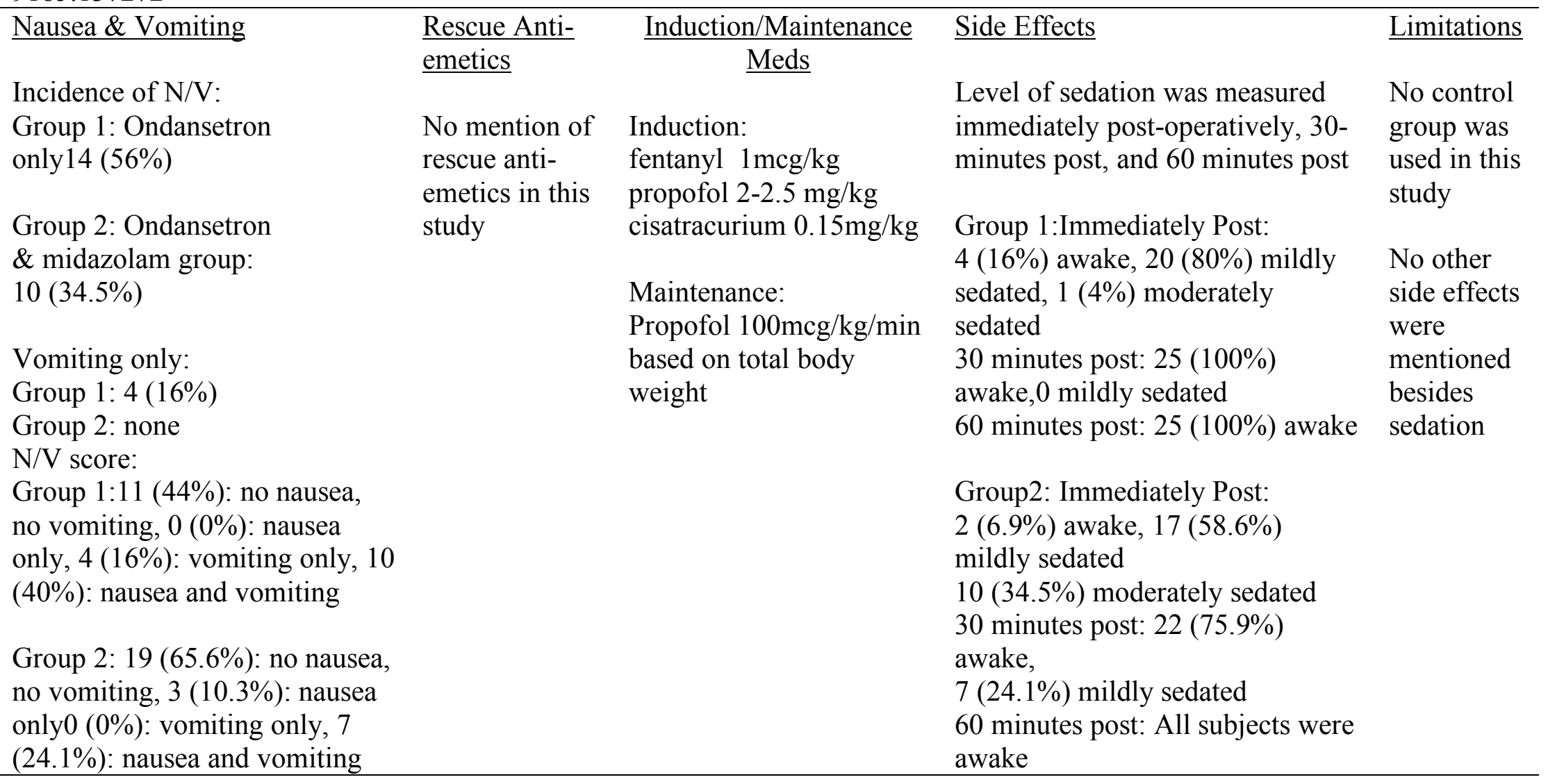


D-2: Celik, M., Dostbil, A., Aksoy, M., Ince, I., Ahiskalioglu, A., Comez, M. \& Fuat Erdem, A. (2014). Is infusion of sub hypnotic propofol as effective as dexamethasone in prevention of post-operative nausea and vomiting related to laparoscopic cholecystectomy? A randomized controlled trial. BioMed Research International, 2015, 1-

5.https://dx.doi.org/10.1155/2015/349806

\begin{tabular}{|c|c|c|c|c|}
\hline Nausea \& Vomiting & $\underline{\text { Rescue Anti-emetics }}$ & Induction/Maintenance Meds & $\underline{\text { Side Effects }}$ & $\underline{\text { Limitations }}$ \\
\hline $0-6$ hours post: & $0-6$ hours post: & Induction: both groups & There was no significant & Type of surgery \\
\hline Group C: $65 \%$ & Group C: $13(32.5 \%)$ & Thiopental sodium $5 \mathrm{mg} / \mathrm{kg}$ & difference among the 3 & and length of \\
\hline Group P: 30\% & Group P: 4 (10\%) & Fentanyl $1 \mathrm{mcg} / \mathrm{kg}$ & groups regarding & anesthesia times \\
\hline Group D: $30 \%$ & Group D: $4(10 \%)$ & Rocuronium & delayed awakening & $\begin{array}{l}\text { were longer } \\
\text { than other }\end{array}$ \\
\hline 6-12 hours post: & 6-12 hours post: & Maintenance: & Group C: $6.1 \pm 1.2 \mathrm{~min}$ & studies \\
\hline Group C: $52.5 \%$ & Group C: $(20 \%)$ & Group D: & Group P: $6.2 \pm 1.21 \mathrm{~min}$ & \\
\hline Group P: 25\% & Group P: $(7.5 \%)$ & $1.0-2.5 \%$ Sevoflurane with $50 \%$ & Group D: $5.9 \pm 1.24 \mathrm{~min}$ & \\
\hline Group D: $20 \%$ & Group D: $(2.5 \%)$ & $\begin{array}{l}\text { oxygen } \\
\text { Fentanyl } 1 \mathrm{mcg} / \mathrm{kg} / \mathrm{h}\end{array}$ & & \\
\hline 12-24 hours post: & 12-24 hours post: & & & \\
\hline Group C: $45 \%$ & No significant & Group P: propofol 1mg/kg/h & & \\
\hline Group P: 20\% & differences among & & & \\
\hline Group D: $10 \%$ & all three groups & & & \\
\hline
\end{tabular}


D-3: Heidari, S., Talakoub, R., \& Yaraghi, Z. (2012). Comparing the preventive effect of midazolam and midazolamdexamethasone on postoperative nausea and vomiting in elective middle ear surgery. Advanced Biomedical Research, 1(9), 1-9. http://doi:10.4103/2277-9175.96052

\section{Mean nausea score} Midazolam group (M):

$1.39 \pm 3.19$

Midazolam/ Dexamethasone group (M+D): $0.42 \pm 1.71$

Mean Vomiting frequency:

PACU: $0.9 \pm 0.29(\mathrm{M}), 0 \pm 0$ $(\mathrm{M}+\mathrm{D})$

6-12h: $1.09 \pm 2.41(\mathrm{M})$

$0.3 \pm 0.8(\mathrm{M}+\mathrm{D})$

12-24h: $0.42 \pm 1.32(\mathrm{M})$, $0.03 \pm 0.17$

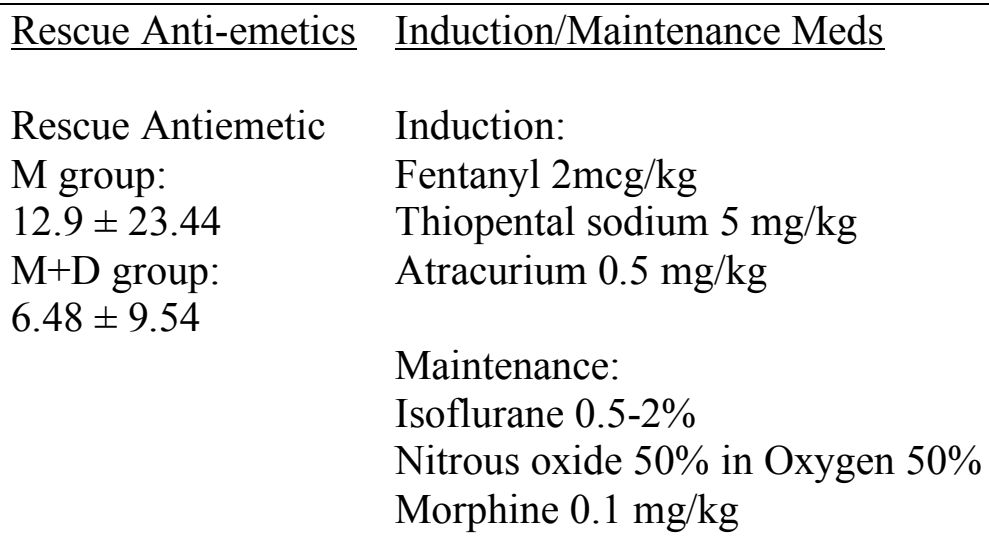

Rescue Anti-emetics Induction/Maintenance Meds

Rescue Antiemetic

$M$ group:

$12.9 \pm 23.44$

$\mathrm{M}+\mathrm{D}$ group:

$6.48 \pm 9.54$

Fe

\section{Induction:}

Fentanyl $2 \mathrm{mcg} / \mathrm{kg}$

Thiopental sodium $5 \mathrm{mg} / \mathrm{kg}$

Atracurium $0.5 \mathrm{mg} / \mathrm{kg}$

\section{Maintenance:}

Isoflurane $0.5-2 \%$

Nitrous oxide 50\% in Oxygen 50\%

Morphine $0.1 \mathrm{mg} / \mathrm{kg}$

Neuromuscular blocker reversal

Neostigmine $0.4 \mathrm{mg} / \mathrm{kg}$

Atropine $0.02 \mathrm{mg} / \mathrm{kg}$

$\begin{array}{ll}\text { Side Effects } & \text { Limitations } \\ \text { Longer recovery } & \text { Small sample } \\ \text { time in PACU in } & \text { size, no } \\ \text { midazolam group } & \text { placebo or } \\ \text { due to more } & \text { control group }\end{array}$

vomiting episodes 
D-4: Honarmand, A., Safavi, M., Khalili, G., \& Mohammadnejad, F. (2012). Prophylactic administration of haloperidol plus midazolam reduces postoperative nausea and vomiting better than using each drug alone in patients undergoing middle ear surgery. Saudi Journal of Anesthesia, 6(2),145-151. https://doi:10.4103/1658-354X.97028

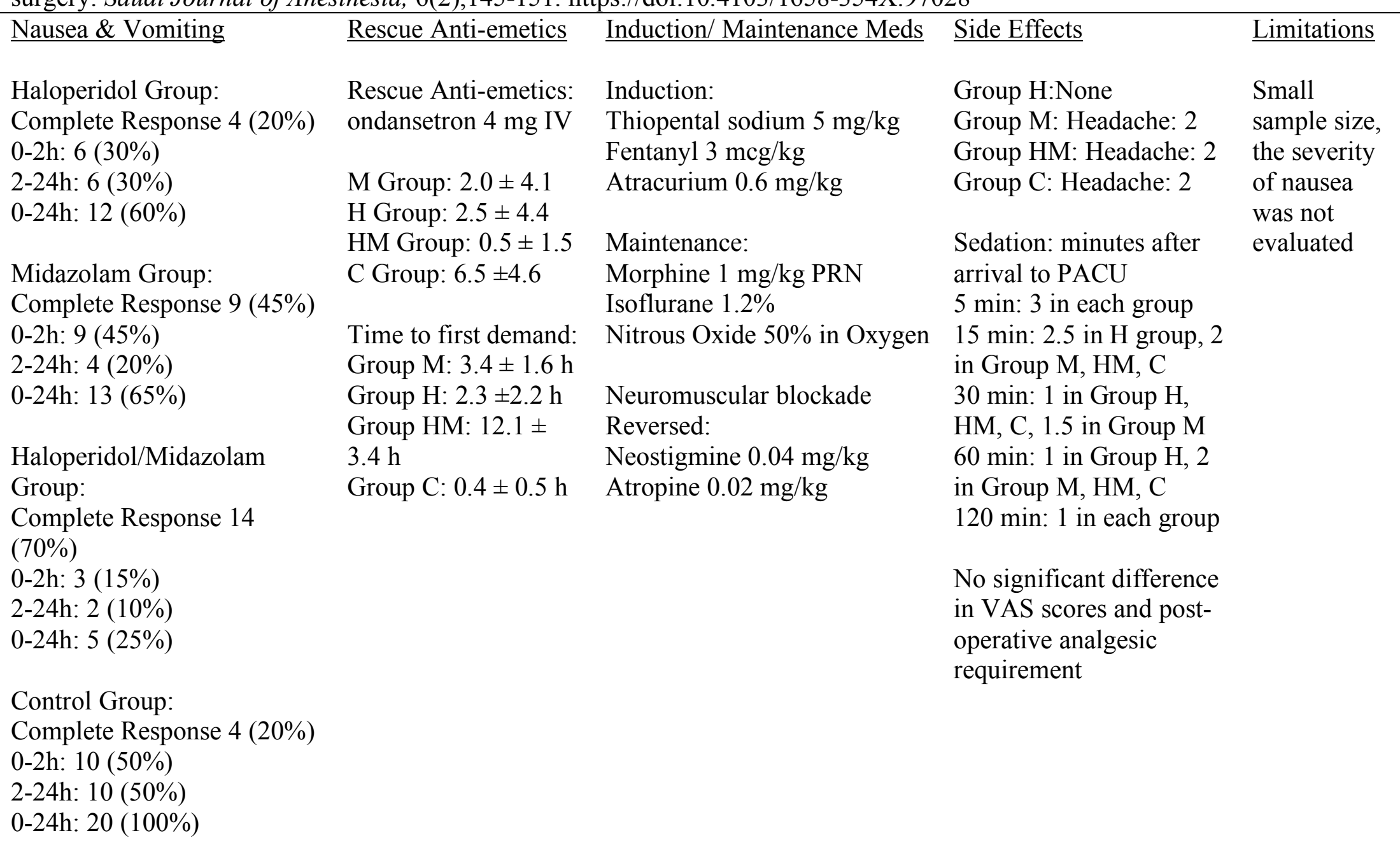


D-5: Joe, H. B., Lee, S. Y., Kim, J.-S., Chang, H. S., Jeong, Y., Jeong, H., \& Park, S. Y. (2016). Effect of total intravenous anesthesia and prophylactic ramosetron on postoperative nausea and vomiting after thyroidectomy: A prospective, randomized controlled study. Journal of International Medical Research, 44(1), 81-88. https://doi.org/10.1177/0300060515607384

\begin{tabular}{ll}
\hline Nausea \& Vomiting & Rescue Anti-emetics \\
TIVAR Group & TIVAR Group: \\
0-6h: & 0-6h: 2 $(5.6 \%)$ \\
4(11.1\%) & 6-24h: 3 $(8.3 \%)$ \\
6-24h: & 0-24h: 4 $(11.1 \%)$ \\
6 (16.7\%) & \\
0-24h: & Sevoflurane Group: \\
7 (19.4\%) & 0-6h: $11(32.4 \%)$ \\
& 6-24h: 6 (16.7\%) \\
Sevoflurane Group & $0-24 \mathrm{~h}: 15(41.7 \%)$ \\
0-6h: & \\
20 $(55.6 \%)$ & \\
6-24h: & \\
11 $(30.6 \%)$ & \\
0-24h: & \\
22 $(61.1 \%)$ &
\end{tabular}

Induction/Maintenance Meds

Sevoflurane Group:

Thiopental sodium $4-5 \mathrm{mg} / \mathrm{kg}$

Sevoflurane in $50 \%$ oxygen

\section{TIVAR Group:}

Ramosetron $0.3 \mathrm{mg}$ prior to

induction

Propofol: induced/maintained (target

blood concentration $3.0-4.5 \mathrm{mcg} / \mathrm{ml}$ )

Remifentanil: induced/ maintained

(target blood concentration 3.5-4.5

$\mathrm{ng} / \mathrm{ml}$ )

Paralytic, reversal, pain med same for both groups: rocuronium 0.6

$\mathrm{m} / \mathrm{kg}$

Pyridostigmine $0.03 \mathrm{mg} / \mathrm{kg}$

Glycopyrrolate $0.002 \mathrm{mg} / \mathrm{kg}$

Ketorolac 30mg

\section{Side Effects}

TIVAR group:

Headache: 16 (44.4\%)

Dizziness: 4 (11.1\%)

Sevoflurane Group:

Headache: 15 (41.7\%)

Dizziness: $10(27.8 \%)$

\section{Limitations}

Lack of TIVA control group (not receiving ramosetron) 
D-6: Kim, E., Park, H., Kang, H., Choi, J. \& Lee, H. (2014). Antiemetic effect of propofol administered at the end of surgery in laparoscopic assisted vaginal hysterectomy. The Korean Society of Anesthesiologists, 66(3): 210-215.

http://dx.doi.org/10.4097/kjae.2014.66.3.210

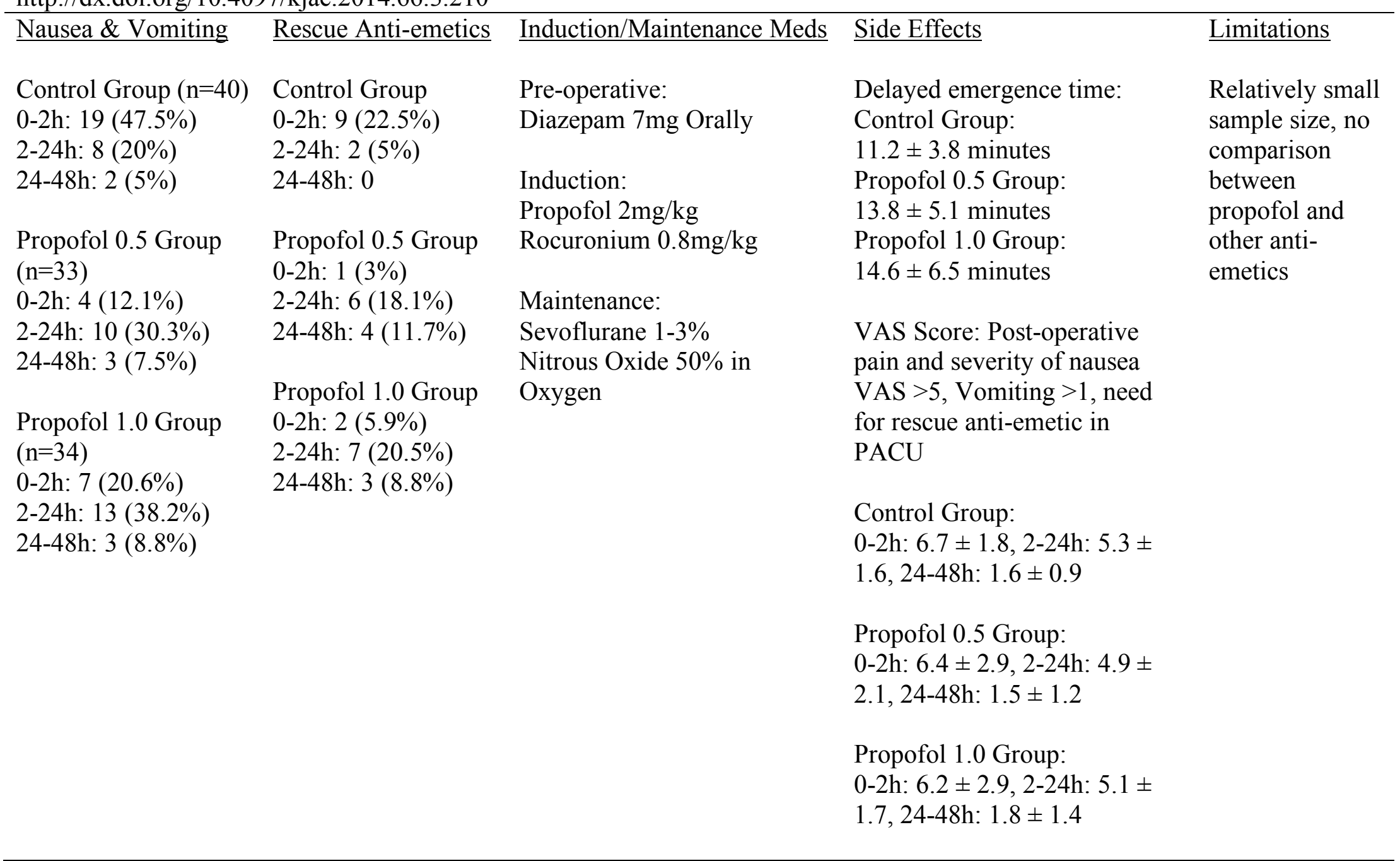


D-7: Naghibi, K., Kashefi, P., Azamoush, H., \& Zabihi, P. (2015). Prevention of postoperative nausea and vomiting with sub hypnotic dose of propofol in patients undergoing lower abdominal surgery: A prospective, randomized, double-blind study.

Advanced Biomedical Research, 4(35). https://doi:10.4103/2277-9175.151239

\begin{tabular}{|c|c|c|c|c|}
\hline Nausea \& Vomiting & $\underline{\text { Rescue Anti-emetics }}$ & Induction/ Maintenance Meds & $\underline{\text { Side Effects }}$ & $\underline{\text { Limitations }}$ \\
\hline $\begin{array}{l}\text { Control Group: } \\
8 \text { (30.8\%) } \\
\text { Propofol 20mg Group: } \\
6(23.1 \%) \\
\text { Propofol 30mg Group: } \\
4(15.2 \%) \\
\text { Metoclopramide } 10 \mathrm{mg} \\
\text { Group } \\
4(15.2 \%) \\
(\mathrm{n}=26 \text { all groups) }\end{array}$ & $\begin{array}{l}\text { Metoclopramide } \\
0.15 \mathrm{mg} / \mathrm{kg} \text { IV used } \\
\text { Control Group: } \\
6(23.1 \%), \text { Mean dose: } \\
12 \pm 4.6 \mathrm{mg} \\
\text { Propofol Group (G1): } \\
4 \text { (15.2\%), Mean dose: } \\
5.2 \pm 2.1 \mathrm{mg} \\
\text { Propofol Group (G2): } \\
2(7.8 \%), \text { Mean dose: } 5 \\
\pm 0.9 \mathrm{mg} \\
\text { Metoclopramide } \\
\text { Group: } \\
2(7.8 \%) \text {, Mean dose: } 6 \\
\pm 1.8 \mathrm{mg}\end{array}$ & $\begin{array}{l}\text { Induction: } \\
\text { Sodium thiopental } 6 \mathrm{mg} / \mathrm{kg} \\
\text { Fentanyl } 2 \mathrm{mg} / \mathrm{kg} \\
\text { Morphine } 0.15 \mathrm{mg} / \mathrm{kg} \\
\text { Atracurium } 0.6 \mathrm{mg} / \mathrm{kg} \\
\text { Maintenance: } \\
\text { Isoflurane 1 MAC } \\
50 \% \text { Nitrous Oxide \& Oxygen }\end{array}$ & $\begin{array}{l}\text { No side effects from } \\
\text { the anti-emetics } \\
\text { were noted in any } \\
\text { group (headache, } \\
\text { dizziness, } \\
\text { drowsiness), } \\
\text { No other side effects } \\
\text { noted in the study }\end{array}$ & $\begin{array}{l}\text { Small sample size, } \\
\text { followed subjects } \\
\text { for only } 24 \text { hours } \\
\text { post-operatively }\end{array}$ \\
\hline
\end{tabular}


D-8: Yimer, H., Ayalew, N., Abdisa, Z. \& Aregawi, A. (2017). Effect of sub-hypnotic dose of propofol on prevention of postoperative nausea and vomiting as part of multimodal antiemetic in patients undergoing open abdominal surgery: A prospective cohort study. International Journal of Surgery Open, 10(2018), 15-20. https://doi.org/10.1016/j.ijso.2017.11.008

\begin{tabular}{|c|c|c|c|c|}
\hline Nausea \& Vomiting & $\underline{\text { Rescue Anti-emetics }}$ & Induction/Maintenance Meds & $\underline{\text { Side Effects }}$ & $\underline{\text { Limitations }}$ \\
\hline $\begin{array}{l}\text { Propofol group: } \\
\text { 0-6h: } 11(30.6 \%) \\
\text { 6-12h: } 8(22.2 \%) \\
\text { 12-24h: } 7(19.4 \%)\end{array}$ & $\begin{array}{l}\text { Reglan } 10 \mathrm{mg} \text { for } \\
\text { severe nausea }(>3 \\
\text { episodes })\end{array}$ & $\begin{array}{l}\text { Induction: } \\
\text { Ketamine } 2 \mathrm{mg} / \mathrm{kg} \text { or thiopental } \\
\text { sodium } 5 \mathrm{mg} / \mathrm{kg} \text {, fentanyl } 0.1 \mathrm{mcg} / \mathrm{kg}\end{array}$ & $\begin{array}{l}\text { Shivering: } \\
\text { Propofol: } 6(16.7 \%) \\
\text { Control: } 5(13.9 \%)\end{array}$ & $\begin{array}{l}\text { Lack of } \\
\text { randomization, } \\
\text { total anti- } \\
\text { emetic }\end{array}$ \\
\hline $\begin{array}{l}\text { Control group: } \\
\text { 0-6h: } 24(66.7 \%) \\
\text { 6-12h: } 14(38.9 \%) \\
\text { 12-24h: } 9(25 \%)\end{array}$ & $\begin{array}{l}\text { Propofol Group: } \\
\text { 0-6h: } 5(13.9 \%) \\
\text { 6-12h: } 2(5.6 \%) \\
\text { 12-24h: } 0\end{array}$ & $\begin{array}{l}\text { Intubation: Suxamethonium } \\
\text { Maintenance: vecuronium halothane } \\
\text { with or without morphine } \\
\text { Reversal: } \\
\text { neostigmine } 0.05 \mathrm{mg} / \mathrm{kg} \\
\text { Atropine } 0.01 \mathrm{mg} / \mathrm{kg}\end{array}$ & & $\begin{array}{l}\text { consumption } \\
\text { not reported } \\
\text { after } 6 \mathrm{~h}, \\
\text { followed } \\
\text { subjects for } \\
24 \mathrm{~h}\end{array}$ \\
\hline
\end{tabular}


Appendix E

Critical Appraisal Skills Programme (CASP) Checklist

Section A: Are the results of the review valid?

Yes Can't Tell No

1. Did the review address a clearly focused question?

2. Did the authors look for the right type of papers?

3. Do you think all the important, relevant studies were included?

4. Did the review's authors do enough to assess quality of the included studies?

5. If the results of the review have been combined, was it reasonable to do so?

Section B: What are the results?

6. What are the overall results of the review?

7. How precise are the results?

\section{Section C: Will the results help locally? $\quad$ Yes Can't Tell No}

8. Can the results be applied to the local population?

9. Were all important outcomes considered?

10. Are the benefits worth the harms and costs? 


\section{Appendix F}

\section{Completed CASP Checklist}

F-1: Abdelhamid, S. \& Kamel, M. (2014). A prospective controlled study to assess the antiemetic effect of midazolam following intragastric balloon insertion. Journal of Anesthesiology Clinical Pharmacology, 30(3), 383-386. https://doi:10.4103/09709185.137272

\section{Section A: Are the results of the trial valid?}

1. Did the trial address a clearly focused issue?

2. Was the assignment of patients to treatments randomized?

3. Were all the patients who entered the trial properly accounted for at its conclusion?

4. Were patients, health workers, and study personnel "blind" to treatment?

5. Were the groups similar at the start of the trial?

6. Aside from the experimental intervention, were the groups treated equally?

\section{Section B: What are the results?}

7. How large was the treatment effect?

8. How precise was the estimate of the treatment effect?

\section{Section C: Will the results help locally?}

9. Can the results be applied in your context?

10. Were all clinically important outcomes considered?

11. Are the benefits worth the harms and costs?
CAN'T

TELL
YES

$\mathbf{X}$

$\mathbf{X}$

$\mathbf{X}$

$\mathbf{X}$

$\mathbf{X}$

$\mathbf{X}$

$\mathbf{X}$
54 Subjects

Significant

reduction in

PONV in combo

group
$\mathbf{X}$

$\mathbf{X}$ 
F-2: Celik, M., Dostbil, A., Aksoy, M., Ince, I., Ahiskalioglu, A., Comez, M. \& Fuat

Erdem, A. (2014). Is infusion of sub hypnotic propofol as effective as dexamethasone in prevention of post-operative nausea and vomiting related to laparoscopic cholecystectomy? A randomized controlled trial. BioMed Research International, 2015, 1-5.https://dx.doi.org/10.1155

\section{Section A: Are the results of the trial valid?}

1. Did the trial address a clearly focused issue?

2. Was the assignment of patients to treatment randomized?

3. Were all the patients who entered the trial properly accounted for at its conclusion?

4. Were patients, health workers, and study personnel "blind" to treatment?

5. Were the groups similar at the start of the trial?

6. Aside from the experimental intervention, were the groups treated equally?

\section{Section B: What are the results?}

7. How large was the treatment effect?

8. How precise was the estimate of the treatment effect?

\section{Section C: Will the results help locally?}

9. Can the results be applied in your context?

10. Were all clinically important outcomes considered?

11. Are the benefits worth the harms and costs?
120 subjects

Propofol \&

Dexamethasone

comparable
CAN'T
TELL

$\mathbf{X}$

$\mathbf{X}$

X

$\mathbf{X}$

$\mathbf{X}$

$\mathbf{X}$

\section{TELL}


F-3: Heidari, S., Talakoub, R., \& Yaraghi, Z. (2012). Comparing the preventive effect of midazolam and midazolam-dexamethasone on postoperative nausea and vomiting in elective middle ear surgery. Advanced Biomedical Research, 1(9), 1-9. http://doi:10.4103/2277-9175.96052

Section A: Are the results of the trial valid?

1. Did the trial address a clearly focused issue?

2. Was the assignment of patients to treatment randomized?

3. Were all the patients who entered the trial properly accounted for at its conclusion?

4. Were patients, health workers, and study personnel "blind" to treatment?

5. Were the groups similar at the start of the trial?

6. Aside from the experimental intervention, were the groups treated equally?

\section{Section B: What are the results?}

7. How large was the treatment effect?

66 subjects

8. How precise was the estimate of the

Reduced treatment effect?

vomiting frequency \& less rescue antiemetic in combo group

\section{Section C: Will the results help locally?}

9. Can the results be applied in your context? $\mathbf{X}$

10. Were all clinically important outcomes considered?

$\mathbf{X}$

11. Are the benefits worth the harms and costs?

NO

\section{TELL}

$\mathbf{X}$

$\mathbf{X}$

$\mathbf{X}$

$\mathbf{X}$

$\mathbf{X}$

$\mathbf{X}$ 
F-4: Honarmand, A., Safavi, M., Khalili, G., \& Mohammadnejad, F. (2012). Prophylactic administration of haloperidol plus midazolam reduces postoperative nausea and vomiting better than using each drug alone in patients undergoing middle ear surgery. Saudi Journal of Anesthesia, 6(2),145-151. https://doi:10.4103/1658-354X.97028

Section A: Are the results of the trial valid?

1. Did the trial address a clearly focused issue?

2. Was the assignment of patients to treatments randomized?

3. Were all the patients who entered the trial properly accounted for at its conclusion?

4. Were patients, health workers, and study personnel "blind" to treatment?

5. Were the groups similar at the start of the trial?

6. Aside from the experimental intervention, were the groups treated equally?

\section{Section B: What are the results?}

7. How large was the treatment effect?

8. How precise was the estimate of the treatment effect?

\section{Section C: Will the results help locally?}

9. Can the results be applied in your context?

10. Were all clinically important outcomes considered?

11. Are the benefits worth the harms and costs?
YES

$\mathbf{X}$

$\mathbf{X}$

$\mathbf{X}$

$\mathbf{X}$

$\mathbf{X}$

$\mathbf{X}$
CAN'T

TELL 
F-5: Joe, H. B., Lee, S. Y., Kim, J.-S., Chang, H. S., Jeong, Y., Jeong, H., \& Park, S. Y. (2016). Effect of total intravenous anesthesia and prophylactic ramosetron on postoperative nausea and vomiting after thyroidectomy: A prospective, randomized controlled study. Journal of International Medical Research, 44(1), 81-88. https://doi.org/10.1177/0300060515607384

Section A: Are the results of the trial valid?

1. Did the trial address a clearly focused issue?

2. Was the assignment of patients to treatments randomized?

3. Were all the patients who entered the trial properly accounted for at its conclusion?

4. Were patients, health workers, and study personnel "blind" to treatment?

5. Were the groups similar at the start of the trial?

6. Aside from the experimental intervention, were the groups treated equally?

\section{Section B: What are the results?}

7. How large was the treatment effect?

8. How precise was the estimate of the treatment effect?

72 subjects

Significant

reduction of

PONV in

propofol group

\section{Section C: Will the results help locally?}

9. Can the results be applied in your context?

$\mathbf{X}$

10. Were all clinically important outcomes considered?

11. Are the benefits worth the harms and costs?

CAN'T

\section{TELL}

$\mathbf{X}$

$\mathbf{X}$

$\mathbf{X}$

X

X

X 
F-6: Kim, E., Park, H., Kang, H., Choi, J. \& Lee, H. (2014). Antiemetic effect of propofol administered at the end of surgery in laparoscopic assisted vaginal hysterectomy. The Korean Society of Anesthesiologists, 66(3): 210-215. http://dx.doi.org/10.4097/kjae.2014.66.3.210

Section A: Are the results of the trial valid?

1. Did the trial address a clearly focused issue?

2. Was the assignment of patients to treatments randomized?

3. Were all the patients who entered the trial properly accounted for at its conclusion?

4. Were patients, health workers, and study personnel "blind" to treatment?

5. Were the groups similar at the start of the trial?

6. Aside from the experimental intervention, were the groups treated equally?

\section{Section B: What are the results?}

7. How large was the treatment effect?

8. How precise was the estimate of the treatment effect?

\section{Section C: Will the results help locally?}

9. Can the results be applied in your context?

10. Were all clinically important outcomes considered?

11. Are the benefits worth the harms and costs?
107 subjects

Significant reduction in PONV compared to control group

$\mathbf{X}$

$\mathbf{X}$

$\mathbf{X}$
YES

X

CAN'T NO

\section{TELL}

X

X

$\mathbf{X}$

$\mathbf{X}$

$\mathbf{X}$ 
F-7: Naghibi, K., Kashefi, P., Azamoush, H., \& Zabihi, P. (2015). Prevention of postoperative nausea and vomiting with sub hypnotic dose of propofol in patients undergoing lower abdominal surgery: A prospective, randomized, double-blind study. Advanced Biomedical Research, 4(35). https://doi:10.4103/2277-9175.151239

Section A: Are the results of the trial valid?

1. Did the trial address a clearly focused issue?

YES

$\mathbf{X}$

2. Was the assignment of patients to treatments randomized?

3. Were all the patients who entered the trial properly accounted for at its conclusion?

4. Were patients, health workers, and study personnel "blind" to treatment?

5. Were the groups similar at the start of the trial?

6. Aside from the experimental intervention, were the groups treated equally?

\section{Section B: What are the results?}

7. How large was the treatment effect?

8. How precise was the estimate of the treatment effect?

\section{Section C: Will the results help locally?}

9. Can the results be applied in your context?

10. Were all clinically important outcomes considered?

11. Are the benefits worth the harms and costs?
$\mathbf{X}$

$\mathbf{X}$

$\mathbf{X}$

$\mathbf{X}$

$\mathbf{X}$
CAN'T NO

\section{TELL}

104 subjects

Propofol groups

required less rescue

antiemetics 
F-8: Yimer, H., Ayalew, N., Abdisa, Z. \& Aregawi, A. (2017). Effect of sub-hypnotic dose of propofol on prevention of postoperative nausea and vomiting as part of multimodal antiemetic in patients undergoing open abdominal surgery: A prospective cohort study. International Journal of Surgery Open, 10(2018), 15-20. https://doi.org/10.1016/j.ijso.2017.11.008

Section A: Are the results of the trial valid?

1. Did the trial address a clearly focused issue?

2. Was the assignment of patients to treatments randomized?

3. Were all the patients who entered the trial properly accounted for at its conclusion?

4. Were patients, health workers, and study personnel "blind" to treatment?

5. Were the groups similar at the start of the trial?

6. Aside from the experimental intervention, were the groups treated equally?

\section{Section B: What are the results?}

7. How large was the treatment effect?

8. How precise was the estimate of the treatment effect?

\section{Section C: Will the results help locally?}

9. Can the results be applied in your context?

10. Were all clinically important outcomes considered?

11. Are the benefits worth the harms and costs?
72 Subjects

Propofol group less incidence of PONV $\&$ less rescue antiemetic for severe nausea
$\mathbf{X}$

$\mathbf{X}$

$\mathbf{X}$

$\mathbf{X}$

\section{TELL}

$\mathbf{X}$

CAN'T NO

\section{TELL}

$\mathbf{X}$

$\mathbf{X}$




\section{Appendix G}

Cross-study Analysis

\begin{tabular}{|c|c|c|c|c|}
\hline $\begin{array}{c}\text { Study } \\
\#\end{array}$ & Nausea \& Vomiting & Rescue Anti-emetics & Adverse Effects & Opioid Use \\
\hline 1 & $\begin{array}{l}\text { Significant reduction in severity of } \\
\text { PONV in ondansetron/ midazolam } \\
\text { group using N/V scores, No } \\
\text { significant reduction of incidence of } \\
\text { PONV }\end{array}$ & $\begin{array}{l}\text { No mention of rescue anti- } \\
\text { emetics in the study }\end{array}$ & $\begin{array}{l}\text { Significant mild sedation in both } \\
\text { groups, significant moderate } \\
\text { sedation in G2 }\end{array}$ & $\begin{array}{l}\text { Fentanyl for } \\
\text { induction }\end{array}$ \\
\hline 2 & $\begin{array}{l}\text { Significant reduction in PONV in } \\
\text { propofol and dexamethasone group } \\
\text { compared to control, Group D \& P } \\
\text { comparable }\end{array}$ & $\begin{array}{l}\text { 0-6h: Group D \& P comparable, } \\
\text { both reduced compared to } \\
\text { control } \\
\text { 6-12h: Group D superior to } \\
\text { Group P } \\
\text { 12-24h: no significant }\end{array}$ & $\begin{array}{l}\text { No significant difference in } \\
\text { delayed emergence among all } \\
\text { groups }\end{array}$ & $\begin{array}{l}\text { Fentanyl for } \\
\text { induction \& } \\
\text { maintenance } \\
\text { for group D }\end{array}$ \\
\hline 3 & $\begin{array}{l}\text { Reduced mean nausea score \& } \\
\text { reduced vomiting frequency in } \\
\text { midazolam/ dexamethasone group } \\
\text { Midazolam alone reduced PONV } \\
\text { more than Haldol alone, } \\
\text { Haldol/midazolam group more } \\
\text { effective }\end{array}$ & $\begin{array}{l}\text { differences among groups } \\
\text { Less rescue anti-emetic in } \\
\text { midazolam/dexamethasone } \\
\text { group }\end{array}$ & $\begin{array}{l}\text { Longer recovery times in PACU } \\
\text { related to more vomiting episodes } \\
\text { in midazolam group }\end{array}$ & $\begin{array}{l}\text { Fentanyl for } \\
\text { induction \& } \\
\text { morphine } \\
\text { during in } \\
\text { both groups }\end{array}$ \\
\hline 4 & $\begin{array}{l}\text { Significant reduction in propofol } \\
\text { group }\end{array}$ & & $\begin{array}{l}\text { No significant adverse effects in } \\
\text { all groups }\end{array}$ & $\begin{array}{l}\text { Fentanyl at } \\
\text { induction, }\end{array}$ \\
\hline
\end{tabular}




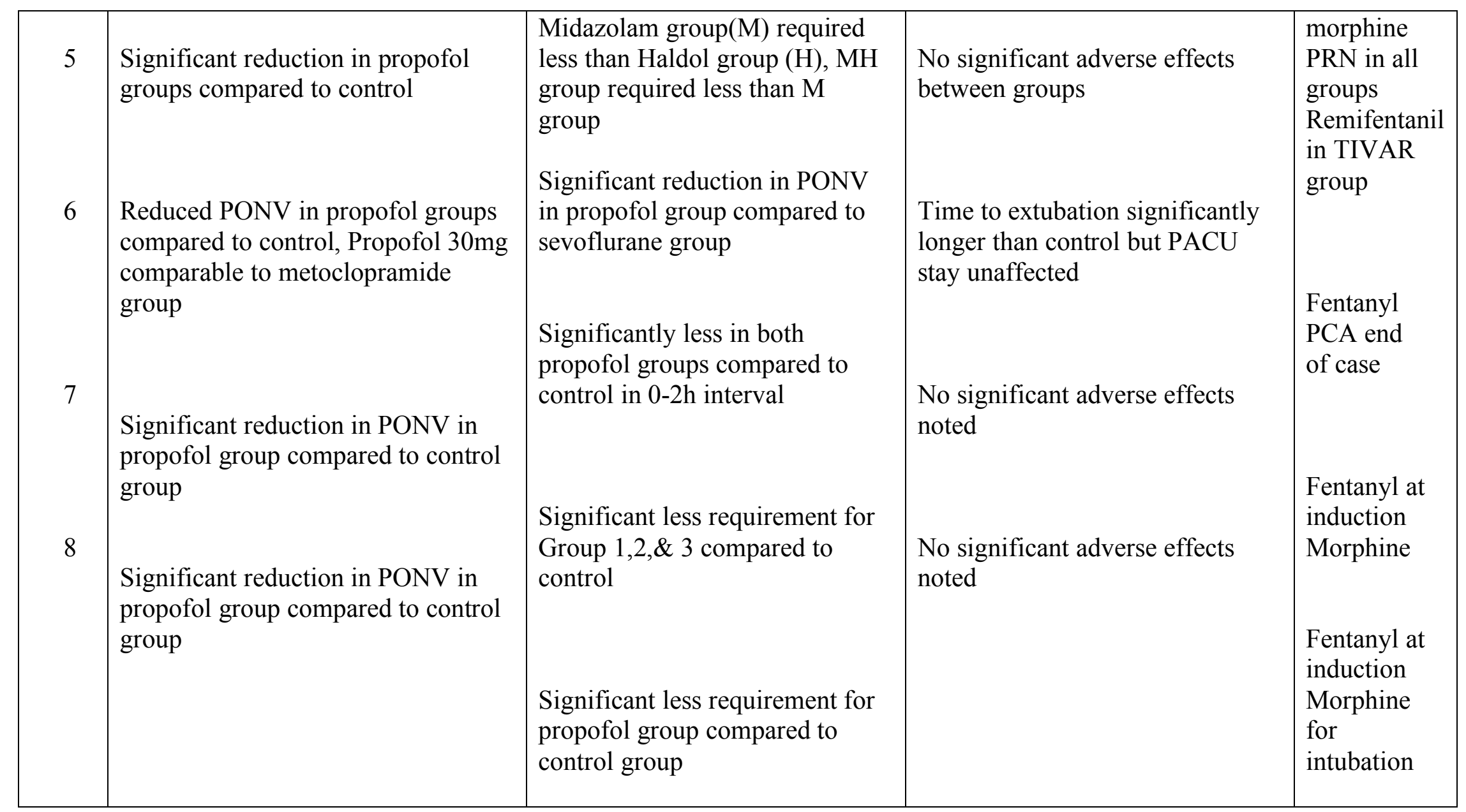


